\title{
INFLUENCE OF SEED SIZE, PLNTING EPTH AND PHOSPHORUS FERTILILIZATION LEVEL ON AND YIELD COMPONENTS CHARACTERS OF LOCAL BROAD BEAN (VICIA FABA L.).
}

Mothanah A. Basit Ali AL-Ameri

Crop. Dept., College of Agric. And Forestry, Mosul Univ

Email:mothna86@yahoo.com

\begin{abstract}
A field experiment was carried out at two sites (Erbil and Mosul) in winter season 2017-2018, to study the effect of three different seed size (small, medium and large) of local broad bean planted in three sowing depths $(5,10$ and $15 \mathrm{~cm})$ using three levels of phosphate fertilizer (zero, 75 and $150 \mathrm{~kg} \mathrm{P}_{2} \mathrm{O}_{5} . \mathrm{ha}^{-1}$ ) in yield and yield components. The experiment executed according to the (R.C.B.D) design and Duncan Multiple range used to compare between treatment means. The results showed that there was no significant effect of seed sizes in most studied traits; The pod length, 100 seeds weight and seeds yield were surpassed at depth $(15 \mathrm{~cm})$ at both sites. The number of pods / plant, 100 seeds weight, seeds yield, and biological yield increased significantly at the second and third fertilization levels at both sites. Pod length, number of seeds / pod and harvest index have exceeded significantly in the second level of fertilization at both sites. The second order interactions showed significant differences between most studied characters.

Key words: broad bean, yield, sowing depth, phosphorus fertilization.
\end{abstract}

Received: 8/10/2019 Accepted: 10/10/2019

\section{INTRODUCTION}

Broad bean (Vicia faba L.) is one of the most important legume crops, it is the cheapest source of protein used in poor countries, the protein percent of in the seeds ranged between $(25-40 \%)$ (Natalia et al, 2008), also the seeds have high contain about percent $(56 \%)$ carbohydrate, minerals, fibers and vitamins in addition to its benefit of raising soil fertility (Carmen et al, 2005). The total area planted for green pods in Iraq is $\left(71578\right.$ ) donum (Iraqi donum $=2500 \mathrm{~m}^{2}$ ) produce $(140542)$ tonnes, the mean yield (1.963) tonnes / donum as green pods (Central Bureau of Statistics and Information Technology, 2010). The area cultivated to produce dry seed in Iraq is $(350,000)$ with mean yield $\left(314 \mathrm{~kg} \cdot \mathrm{ha}^{-1}\right)$ (Arab Agricultural Development Organization, Khartoum, 2012). Selecting the appropriate size of seeds and determining the convenient depth of sowing may have positive impact on increasing yield due to the increasing of rate, speed of germination and establishment, which ultimately reflects on yields. Some studies were carried out to determine the best size of broad bean seed, Hussain et al. (2013) found that large seeds planted in depth (4 and $8 \mathrm{~cm}$ ) surpassed in seed germination percent. Mekkei (2014) found a significant superiority of plants grown from large seeds comparing with medium and small seeds particularly in 100 seed weight and seed yield, but the seed size did not affect the number of pods /plant, number of seeds /pod, biological yield, and harvest index. Siddig and Idris (2015) found that the germination\% of medium and large seeds which planted in $(5 \mathrm{~cm})$ depth increased comparing with small seeds, nevertheless they did not observe significant differences in germination \% between the sowing 
depths. However, Idris (2008) did not observe significant differences between four different seed sizes in number of pods /plants, number of seeds / pod, 100 seed weight and seed yield. Al-Anbari et al. (2010) observed that $(10 \mathrm{~cm})$ depth surpassed in seed yield comparing with $(5$ and $15 \mathrm{~cm})$ depth. $(5 \mathrm{~cm})$ depth surpassed in 100 seed weight. Singh et al. (2010) observed a significant superiority of the large seeds sown at (12 $\mathrm{cm}$ ) depth in the number of days to germination comparing with small, medium and large seeds at the depths (4 and $8 \mathrm{~cm}$ ); The (medium sized) seeds planted in $(4 \mathrm{~cm})$ depth surpassed in seed yield in contrast to (small, large and very large) seed planted on $(4,8$ and $12 \mathrm{~cm})$ depth. The small seeds sown at $(4 \mathrm{~cm})$ gave the longest pods, highest number of pods /plant and seeds/ pod. Issa (2009) reported a significant superiority with $\left(120 \mathrm{~kg} \mathrm{P}_{2} \mathrm{O}_{5} \cdot \mathrm{ha}^{-1}\right)$ in the number of pods /plant, 100 seed weight and seed yield comparing with ( 0 and $\left.100 \mathrm{~kg} \mathrm{P}_{2} \mathrm{O}_{5} \cdot \mathrm{ha}^{-1}\right)$. Hashemdhadi (2013) different from refer list study the impact of phosphate levels $\left(0,40,80,120 \mathrm{~kg} \mathrm{P}_{2} \mathrm{O}_{5} . \mathrm{ha}^{-1}\right)$ in yield and yield components of broad bean, the researcher did not notice any significant differences between all levels of fertilization on the number of pods / plant, 100 seed weight and seeds yield. Huthily and al-Hassani (2014) noticed that phosphate fertilization with $\left(120 \mathrm{~kg} \mathrm{P}_{2} \mathrm{O}_{5} \mathrm{~kg}\right.$. ha $\left.{ }^{-1}\right)$ have positive effect in the number of pods / plant, number of seeds /pod, 100 seed weight and seed yield /plant comparing with (zero $\mathrm{P}_{2} \mathrm{O}_{5} \mathrm{~kg}$. ha ${ }^{-1}$ ). Kubure et al. (2016), use two levels of phosphate fertilization ( 0 and $\left.46 \mathrm{~kg} \mathrm{P}_{2} \mathrm{O}_{5} . \mathrm{ha}^{-1}\right)$, on three broad beans genotype, the fertilizer dose $\left(46 \mathrm{~kg} \mathrm{P}_{2} \mathrm{O}_{5} . \mathrm{ha}^{-1}\right)$ surpassed in pod length, 100 seed weight, seed yield and biological yield, while the number of days for maturity, number of pods /plant and harvest index did not affect. Sarkar et al. (2017) found that phosphate fertilization rate $\left(75 \mathrm{~kg} \mathrm{P}_{2} \mathrm{O}_{5} . \mathrm{ha}^{-1}\right)$ increase the number of seeds / pod, 100 seed weight and seed yield comparing with $\left(0,25,50 \mathrm{P}_{2} \mathrm{O}_{5} \mathrm{~kg}\right.$. ha $\left.{ }^{-1}\right)$. The current study aims to find the effect of treatment combination of three size different seed (small, medium and large) planted in three depths $(5,10,15 \mathrm{~cm})$ with three levels of phosphate fertilization $(0$, 75 and $150 \mathrm{~kg} \mathrm{P}_{2} \mathrm{O}_{5}$. ha ${ }^{-1}$ ) on yield and yield components of the local broad bean crop.

\section{MATERIAL AND METHODS}

A field experiment was carried out in two locations, the first at private farmer field in Erbil and the second in the Field of Crops Department / Collage of Agriculture and Forestry / University of Mosul, during growing season 2017/2018. The experiment included three factors: The first is three different seed sizes of local broad bean i.e. small (700-1000 mg / seed), medium (1001-1500 mg / seed) and large (more than $1500 \mathrm{mg} / \mathrm{seed}$ ) according to (Al- Rifaee et al, 2004) and (Mekkei, 2014) methods, The second factor is three sowing depths $(5,10,15 \mathrm{~cm})$ and the third factor is three levels of phosphate fertilization $\left(0,75,150 \mathrm{~kg} \mathrm{P}_{2} \mathrm{O}_{5} \cdot \mathrm{h}^{-1}\right)$ in the form of triple super phosphate $(46 \% \mathrm{P})$ added at the beginning of sowing. Mosul site was planted in (4/12/2017), Erbil was at (7/12/2017), the field divides to three replicas each one contain (27) experimental units due to the number of combination treatments by using Randomized Complete Block Design (R. C. B. D).The experimental unit consist of four lines each Randomized at $(3 \mathrm{~m})$ length, the distance between lines $(60 \mathrm{~cm})$ and between plants $(30 \mathrm{~cm})$. Urea Fertilizer $(44 \mathrm{~kg} / \mathrm{ha})$ was added to all the experimental units, half dose after germination and the remainder at the beginning of the flowering stage, as recommended by (Boras et al 2006). The data were analyzed according to 
the (R.C.B.D) design, Duncan multiple range test (1955) treatment. The percentage of field emergence was calculated from the number of grown seeds to the number of planted seeds per experimental unit. Then ten plants were randomly taken from the median lines to calculate the maturity of $(50 \%)$ of pods, mean of pod length $(\mathrm{cm})$, number of pods /plant, number of seeds / pod (by dividing the number of seeds by the number of pods for (10) plants, seed index (gm) as (100) seeds weight, seed yield (gm /Plant), biological yield (gm /plant) which represents the weight of the total dry mater, and the Harvest index (HI) (\%) using the formula mentioned by (Sharma and Smith, 1986) Harvest index $=($ seed yield $/$ biological yield $) \times 100$.

Final germination \% (field emergence):

\section{RESULTS AND DISCUSSION}

The results in table (1) showed that the final emergence $\%$ was not affected by the seed sizes at both sites. The final emergence $\%$ in the seeds sown at $(10 \mathrm{~cm})$ depth surpassed significantly in two locations, the low germination $\%$ in $(5 \mathrm{~cm})$ depth is due to the lack of moisture in the surface layer. While the reduction of final germination in depth $(15 \mathrm{~cm})$ may be due to mechanical resistance of penetration of the plumule (shoot) to soil then the failure in emergence is larger in comparison to $(10 \mathrm{~cm})$ depth, these results corresponds to the findings of Singh et.al (2010). Fertilizer rates showed no significant differences on field emergence at both sites. The interaction between seed sizes and depth was highest at $(10 \mathrm{~cm})$ depth despite of seed sizes at both sites. Interaction between seed sizes and fertilization did not significantly affect this character in both sites. The highest final emergence $\%$ in the interaction between depths and fertilizer doses in both location was recorded for the depth $(10 \mathrm{~cm})$ with all fertilizers levels $\left(0,75\right.$ and $\left.150 \mathrm{~kg} \mathrm{P}_{2} \mathrm{O}_{5} . \mathrm{ha}^{-1}\right)$. In the triinteraction, the highest percentage of final emergence at both site was recorded for all seed size at all levels of fertilization sown at $(10 \mathrm{~cm})$ depth.

The number of days until maturity of $50 \%$ of pods:

From table (2) there was no significant difference in the number of days to maturity of 50\% of the pods between the seed sizes in two locations. The number of days was decreased significantly at $(5$ and $10 \mathrm{~cm})$ depth comparing with $(15 \mathrm{~cm})$ in Erbil location, while there was no significant differences at Mosul location. Maturity of 50\% of pods decreased significantly in third level of the fertilization in Erbil location, this results agree with Kubure et al (2016). The number of days to maturity of $50 \%$ of the pods increased significantly at the depth $(15 \mathrm{~cm})$ with small and medium seeds at Erbil location (139 days) for both size, while there were no significant differences of this interaction in Mosul, this due to the environmental conditions between the sites. The interaction between the seeds size and levels of 
Mesopotamia J. of Agric.

Vol. (47) No. (2) 2019
ISSN: 2224 - 9796 (Online)

ISSN: 1815 - $316 \mathrm{X}$ (Print)

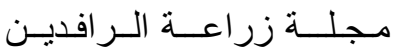

المجلد (47) العدد (2) 2019

Table (1): Effect of seed size, sowing depth, phosphorus fertilization and their interaction on final field emergence.

\begin{tabular}{|c|c|c|c|c|c|}
\hline \multirow{4}{*}{$\begin{array}{l}\text { Seed } \\
\text { size }\end{array}$} & \multicolumn{5}{|c|}{ Erbil location } \\
\hline & \multirow{3}{*}{$\begin{array}{c}\text { Sowing } \\
\text { depth }(\mathrm{cm})\end{array}$} & \multicolumn{3}{|c|}{ phosphorus fertilizers rate } & \multirow{3}{*}{$\begin{array}{c}\text { Size X Depth } \\
\text { mean }\end{array}$} \\
\hline & & 0 & 75 & 150 & \\
\hline & & \multicolumn{3}{|c|}{ size, depth and fertilizers } & \\
\hline \multirow{3}{*}{ Small } & 5 & $69.5 \mathrm{j}$ & $72.0 \mathrm{ij}$ & $74.4 \mathrm{hi}$ & $71.9 \mathrm{c}$ \\
\hline & 10 & $83.2 \mathrm{a}-\mathrm{c}$ & $83.2 \mathrm{a}-\mathrm{c}$ & $84.3 \mathrm{ab}$ & $83.6 \mathrm{a}$ \\
\hline & 15 & $79.6 \mathrm{c}-\mathrm{g}$ & $80.3 \mathrm{~b}-\mathrm{g}$ & $77.0 \mathrm{gh}$ & $79.0 \mathrm{~b}$ \\
\hline \multirow{3}{*}{ Medium } & 5 & $71.0 \mathrm{ij}$ & $70.8 \mathrm{ij}$ & $72.6 \mathrm{ij}$ & $71.5 \mathrm{c}$ \\
\hline & 10 & $81.7 \mathrm{~b}-\mathrm{f}$ & $84.4 \mathrm{ab}$ & 82.6 a-e & $82.9 \mathrm{a}$ \\
\hline & 15 & $79.1 \mathrm{c}-\mathrm{g}$ & $78.7 \mathrm{e}-\mathrm{g}$ & $77.9 \mathrm{f}-\mathrm{h}$ & $78.6 \mathrm{~b}$ \\
\hline \multirow{3}{*}{ Large } & 5 & $71.5 \mathrm{ij}$ & $71.0 \mathrm{ij}$ & $72.9 \mathrm{ij}$ & $71.8 \mathrm{c}$ \\
\hline & 10 & $82.9 \mathrm{a}-\mathrm{d}$ & $81.1 \mathrm{~b}-\mathrm{g}$ & $86.3 \mathrm{a}$ & $83.4 \mathrm{a}$ \\
\hline & 15 & $78.9 \mathrm{~d}-\mathrm{g}$ & $82.0 \mathrm{~b}-\mathrm{f}$ & $78.0 \mathrm{fg}$ & $79.6 \mathrm{~b}$ \\
\hline \multicolumn{2}{|c|}{ fertilizers mean } & $77.5 \mathrm{a}$ & $78.2 \mathrm{a}$ & $78.4 \mathrm{a}$ & \\
\hline \multicolumn{2}{|c|}{ Size } & \multicolumn{3}{|c|}{ Size $\mathrm{X}$ fertilizers mean } & Size mean \\
\hline \multicolumn{2}{|c|}{ Small } & $77.4 \mathrm{a}$ & $78.5 \mathrm{a}$ & $78.6 \mathrm{a}$ & $78.2 \mathrm{a}$ \\
\hline \multicolumn{2}{|c|}{ Medium } & $77.2 \mathrm{a}$ & $78.0 \mathrm{a}$ & $77.7 \mathrm{a}$ & $77.6 \mathrm{a}$ \\
\hline \multicolumn{2}{|c|}{ Large } & $77.8 \mathrm{a}$ & $78.0 \mathrm{a}$ & $79.0 \mathrm{a}$ & $78.3 \mathrm{a}$ \\
\hline \multicolumn{2}{|c|}{ Depth } & \multicolumn{3}{|c|}{ Depth $X$ fertilizers mean } & Depth mean \\
\hline \multicolumn{2}{|c|}{5} & $70.6 \mathrm{e}$ & $71.3 \mathrm{de}$ & $73.3 \mathrm{~d}$ & $71.7 \mathrm{c}$ \\
\hline \multicolumn{2}{|c|}{10} & $82.6 \mathrm{a}$ & $82.9 \mathrm{a}$ & $84.4 \mathrm{a}$ & $83.3 \mathrm{a}$ \\
\hline \multicolumn{2}{|c|}{15} & $79.2 \mathrm{bc}$ & $80.4 \mathrm{~b}$ & $77.6 \mathrm{c}$ & $79.1 \mathrm{~b}$ \\
\hline \multicolumn{6}{|c|}{ Mosul location } \\
\hline \multirow{3}{*}{ Small } & 5 & $71.4 \mathrm{~g}$ & $73.4 \mathrm{fg}$ & $77.4 \mathrm{c}-\mathrm{e}$ & $74.0 \mathrm{c}$ \\
\hline & 10 & $86.2 \mathrm{a}$ & $86.7 \mathrm{a}$ & $85.7 \mathrm{a}$ & $86.2 \mathrm{a}$ \\
\hline & 15 & $79.5 \mathrm{c}$ & $80.0 \mathrm{c}$ & 77.2 c-e & $78.9 \mathrm{~b}$ \\
\hline \multirow{3}{*}{ Medium } & 5 & $73.4 \mathrm{fg}$ & $73.4 \mathrm{fg}$ & $73.9 \mathrm{e}-\mathrm{g}$ & $73.5 \mathrm{c}$ \\
\hline & 10 & $86.3 \mathrm{a}$ & $85.6 \mathrm{a}$ & $85.9 \mathrm{a}$ & $85.9 \mathrm{a}$ \\
\hline & 15 & $80.5 \mathrm{c}$ & $81.1 \mathrm{bc}$ & 77.4 c-e & $79.6 \mathrm{~b}$ \\
\hline \multirow{3}{*}{ Large } & 5 & $73.9 \mathrm{e}-\mathrm{g}$ & $73.7 \mathrm{e}-\mathrm{g}$ & $75.2 \mathrm{~d}-\mathrm{f}$ & $74.2 \mathrm{c}$ \\
\hline & 10 & $87.0 \mathrm{a}$ & $84.2 \mathrm{ab}$ & $86.9 \mathrm{a}$ & $86.0 \mathrm{a}$ \\
\hline & 15 & $80.2 \mathrm{c}$ & $80.8 \mathrm{bc}$ & $78.5 \mathrm{~cd}$ & $79.8 \mathrm{~b}$ \\
\hline \multicolumn{2}{|c|}{ fertilizers mean } & $79.8 \mathrm{a}$ & $79.8 \mathrm{a}$ & $79.8 \mathrm{a}$ & \\
\hline \multicolumn{2}{|c|}{ Size } & & fertilizer & & Size mean \\
\hline & mall & $79.0 \mathrm{a}$ & $80.0 \mathrm{a}$ & $80.1 \mathrm{a}$ & $79.7 \mathrm{a}$ \\
\hline & dium & $80.0 \mathrm{a}$ & $80.0 \mathrm{a}$ & $79.1 \mathrm{a}$ & $79.7 \mathrm{a}$ \\
\hline & arge & $80.3 \mathrm{a}$ & $79.6 \mathrm{a}$ & $80.2 \mathrm{a}$ & $80.0 \mathrm{a}$ \\
\hline & epth & $\mathrm{De}$ & fertilize & an & Depth mean \\
\hline & 5 & $72.9 \mathrm{e}$ & $73.5 \mathrm{e}$ & $75.5 \mathrm{~d}$ & $73.9 \mathrm{c}$ \\
\hline & 10 & $86.5 \mathrm{a}$ & $85.5 \mathrm{a}$ & $86.2 \mathrm{a}$ & $86.0 \mathrm{a}$ \\
\hline & 15 & $80.0 \mathrm{~b}$ & $80.6 \mathrm{~b}$ & $77.7 \mathrm{c}$ & $79.4 \mathrm{~b}$ \\
\hline
\end{tabular}

Means followed by similar letters within factors or their interactions are not significantly d ifferent according to DMRT (1955), at 5\% probability. 
Mesopotamia J. of Agric.

Vol. (47) No. (2) 2019
ISSN: 2224 - 9796 (Online)

ISSN: 1815 - $316 \mathrm{X}$ (Print)
مجلــــة زر اعسـة الـر افديـن

المجلد (47) العدد (2) 2019

Table (2): Effect of seed size, sowing depth, phosphorus fertilization and their interaction on number of days until $(50 \%)$ maturity of the plants

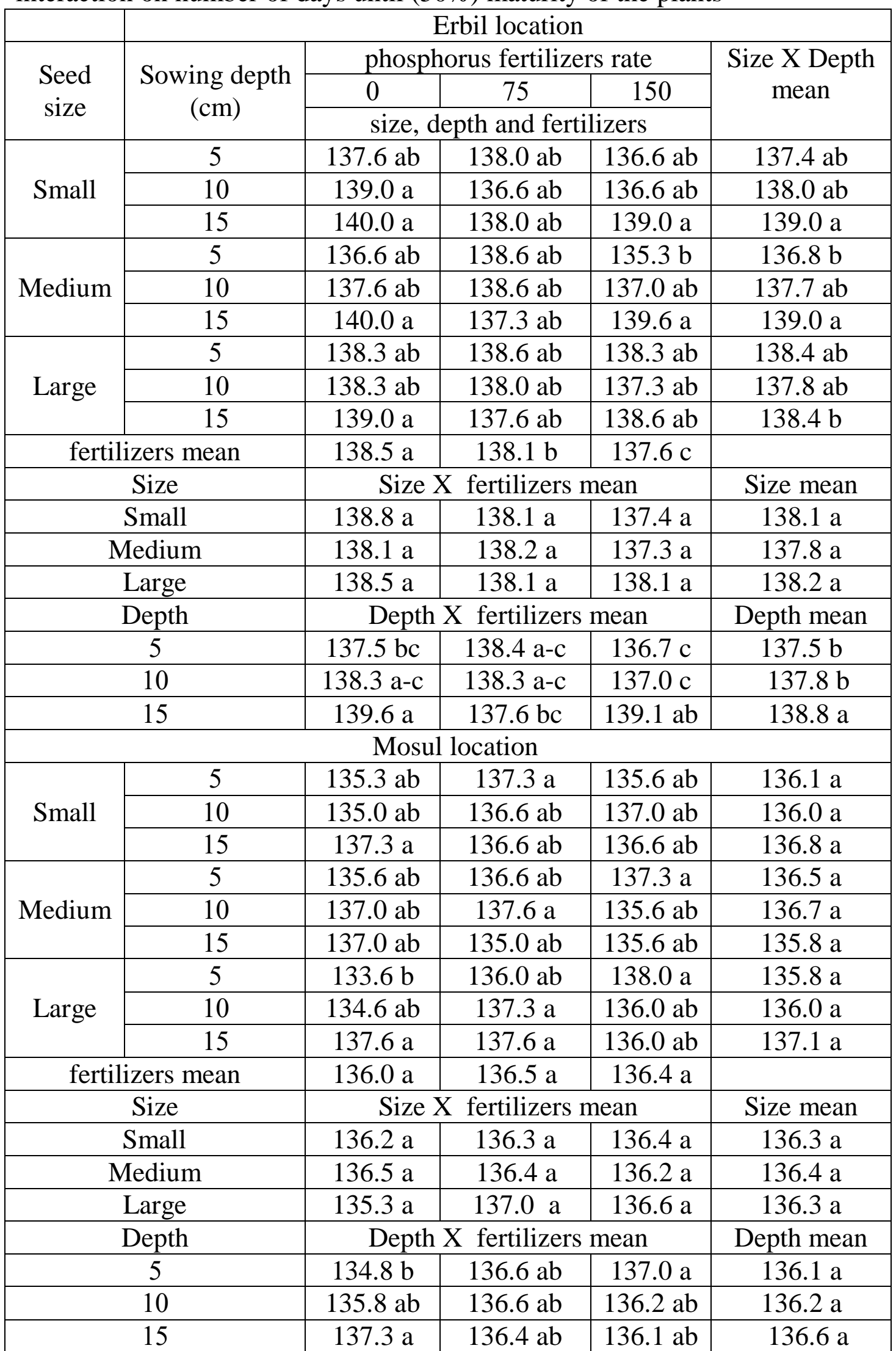

Means followed by similar letters within factors or their interactions are not significantly different according to DMRT (1955), at 5\% probability. 
fertilization did not affect the number of days until maturity of 50\% of the pods at both sites. The interaction between the depths and fertilization showed that (5and $10 \mathrm{~cm})$ depths with $\left(150 \mathrm{~kg} \mathrm{P}_{2} \mathrm{O}_{5} \cdot \mathrm{ha}^{-1}\right)$ decrease the day to maturing at Erbil only, and at $(5 \mathrm{~cm})$ depth with the $\left(0 \mathrm{~kg} \mathrm{P}_{2} \mathrm{O}_{5} \cdot \mathrm{ha}^{-1}\right)$ at Mosul. In the triple interaction the maximum number of days to $50 \%$ of maturity was recorded for the small seeds at a depth of $(15 \mathrm{~cm})$ without fertilization (140 days) with a delay of about (4.7 days) from medium seeds planted at $(5 \mathrm{~cm})$ depth in Erbil. at Mosul site the difference in the number of days till maturity of large size seeds sown at $(5 \mathrm{~cm})$ depth with the third level of fertilization and plants growing from large seeds at $(5 \mathrm{~cm})$ depth with the level of fertilization (zero) was (4.4days). In general the plants were maturated earlier at Mosul than Erbil perhaps the temperature was higher at Mosul which leads to accelerate at maturation.

Pod length $(\mathrm{cm})$ :

Seed size did not affect the pod length at both sites (table 3), but the length of the pods from plants of $(15 \mathrm{~cm})$ depth exceeded significantly comparing with those planted at $(5$ and $10 \mathrm{~cm})$ depth at both sites. The plants fertilized with $\left(75 \mathrm{~kg} \mathrm{P}_{2} \mathrm{O}_{5}\right.$. $\mathrm{ha}^{-1}$ ) exceeded significantly the pods length at both sites, the third level of fertilizer did not differ from that at Mosul only while the pod length decreased significantly at zero level in phosphate at both sites. The pod length increased significantly at (15 $\mathrm{cm})$ depth despite of seed sizes, while the pod length decreased significantly whenever the depth is reduced in Erbil, Generally $(10$ and $15 \mathrm{~cm})$ depth positively affect most studied traits, this effect attributed to the high moisture content in these depths especially at $(15 \mathrm{~cm})$, these results were similar at Mosul location. In the interaction of seeds size and fertilization levels the pod length increased significantly at $\left(75 \mathrm{~kg} \mathrm{P}_{2} \mathrm{O}_{5} . \mathrm{ha}^{-1}\right)$ for all sizes of seed (small, medium and large) at both sites, in addition to the third level of fertilization at Mosul site, this was coincided with the results of Kubure et al (2016). The pod length increased at $(15 \mathrm{~cm})$ depth with the three levels of fertilization at Erbil site and with the second and third Level of fertilization at Mosul site. In the triple interaction the longest pods produced at $(15 \mathrm{~cm})$ depth with all seed sizes and all fertilizer levels, especially the second and the third levels of fertilization, at both sites. The overview results showed that the (15 and 10 $\mathrm{cm}$ ) depth and (75 and $150 \mathrm{~kg} \mathrm{P}_{2} \mathrm{O}_{5} . \mathrm{ha}^{-1}$ ) had generally positive effect on most plant growth characters.

Number of pods / plant:

Table (4) denotes that there is no significant differences in the number of pods / plant with different seeds size, this is in consistence with the results of Idris (2008) and Mekkei (2014), The depth $(10 \mathrm{~cm})$ gave the high number of pods / plant in both sites (10.44 and 9.48 pod) for Erbil and Mosul respectively. The fertilization levels (150 and $75 \mathrm{~kg} \mathrm{P}_{2} \mathrm{O}_{5} . \mathrm{ha}^{-1}$ ) also gave the highest number of pods / plant at both sites, this results in consistent with Issa (2009), Hashemabadi (2013), Huthily and alHassani (2014). The interaction between all sizes of seed sown in $(10 \mathrm{~cm})$ depth were significantly higher in number of pods / plant comparing with other interactions. 
Table (3): Effect of seed size, sowing depth, phosphorus fertilization and their interaction on pod length $(\mathrm{cm})$.

\begin{tabular}{|c|c|c|c|c|c|}
\hline \multirow{4}{*}{$\begin{array}{l}\text { Seed } \\
\text { size }\end{array}$} & \multicolumn{5}{|c|}{ Erbil location } \\
\hline & \multirow{3}{*}{$\begin{array}{c}\text { Sowing } \\
\text { depth }(\mathrm{cm})\end{array}$} & \multicolumn{3}{|c|}{ phosphorus fertilizers rate } & \multirow{3}{*}{$\begin{array}{c}\text { Size X Depth } \\
\text { mean }\end{array}$} \\
\hline & & 0 & 75 & 150 & \\
\hline & & \multicolumn{3}{|c|}{ size, depth and fertilizers } & \\
\hline \multirow{3}{*}{ Small } & 5 & $9.7 \mathrm{~g}-\mathrm{j}$ & $10.7 \mathrm{e}-\mathrm{i}$ & $9.8 \mathrm{f}-\mathrm{j}$ & $10.1 \mathrm{c}$ \\
\hline & 10 & $11.3 \mathrm{de}$ & $12.8 \mathrm{bc}$ & $11.3 \mathrm{de}$ & $11.8 \mathrm{~b}$ \\
\hline & 15 & $13.3 \mathrm{a}-\mathrm{c}$ & $14.4 \mathrm{a}$ & $13.9 \mathrm{a}-\mathrm{c}$ & $13.9 \mathrm{a}$ \\
\hline \multirow{3}{*}{ Medium } & 5 & 9.4 hij & $10.1 \mathrm{e}-\mathrm{j}$ & $9.3 \mathrm{j}$ & $9.6 \mathrm{c}$ \\
\hline & 10 & $10.9 \mathrm{e}-\mathrm{g}$ & $12.5 \mathrm{~cd}$ & $11.0 \mathrm{e}-\mathrm{g}$ & $11.5 \mathrm{~b}$ \\
\hline & 15 & $13.6 \mathrm{a}-\mathrm{c}$ & $14.3 \mathrm{ab}$ & $12.9 \mathrm{bc}$ & $13.6 \mathrm{a}$ \\
\hline \multirow{3}{*}{ Large } & 5 & $9.3 \mathrm{ij}$ & $10.7 \mathrm{e}-\mathrm{h}$ & $9.7 \mathrm{~g}-\mathrm{j}$ & $9.9 \mathrm{c}$ \\
\hline & 10 & $11.2 \mathrm{~d}-\mathrm{f}$ & $12.5 \mathrm{~cd}$ & $11.3 \mathrm{de}$ & $11.7 \mathrm{~b}$ \\
\hline & 15 & $13.4 \mathrm{a}-\mathrm{c}$ & $13.6 \mathrm{a}-\mathrm{c}$ & $13.3 \mathrm{a}-\mathrm{c}$ & $13.4 \mathrm{a}$ \\
\hline \multicolumn{2}{|c|}{ fertilizers mean } & $11.3 \mathrm{~b}$ & $12.4 \mathrm{a}$ & $11.4 \mathrm{~b}$ & \\
\hline \multicolumn{2}{|c|}{ Size } & \multicolumn{3}{|c|}{ Size $X$ fertilizers mean } & Size mean \\
\hline \multicolumn{2}{|c|}{ Small } & $11.4 \mathrm{c}$ & $12.6 \mathrm{a}$ & $11.7 \mathrm{bc}$ & $11.9 \mathrm{a}$ \\
\hline \multicolumn{2}{|c|}{ Medium } & $11.3 \mathrm{c}$ & $12.3 \mathrm{ab}$ & $11.1 \mathrm{c}$ & $11.5 \mathrm{a}$ \\
\hline \multicolumn{2}{|c|}{ Large } & $11.3 \mathrm{c}$ & $12.3 \mathrm{ab}$ & $11.4 \mathrm{c}$ & $11.7 \mathrm{a}$ \\
\hline \multicolumn{2}{|c|}{ Depth } & \multicolumn{3}{|c|}{ Depth $X$ fertilizers mean } & Depth mean \\
\hline \multicolumn{2}{|c|}{5} & $9.5 \mathrm{~d}$ & $10.5 \mathrm{c}$ & $9.6 \mathrm{~d}$ & $9.8 \mathrm{c}$ \\
\hline \multicolumn{2}{|r|}{10} & $11.1 \mathrm{c}$ & $12.6 \mathrm{~b}$ & $11.2 \mathrm{c}$ & $11.7 \mathrm{~b}$ \\
\hline \multicolumn{2}{|r|}{15} & $13.4 \mathrm{a}$ & $14.1 \mathrm{a}$ & $13.4 \mathrm{a}$ & $13.6 \mathrm{a}$ \\
\hline \multicolumn{6}{|c|}{ Mosul location } \\
\hline \multirow{3}{*}{ Small } & 5 & $7.3 \mathrm{fg}$ & $8.6 \mathrm{a}-\mathrm{f}$ & $7.9 \mathrm{~d}-\mathrm{g}$ & $7.9 \mathrm{~b}$ \\
\hline & 10 & $7.9 \mathrm{~d}-\mathrm{g}$ & $8.3 \mathrm{c}-\mathrm{g}$ & $7.9 \mathrm{~d}-\mathrm{g}$ & $8.0 \mathrm{~b}$ \\
\hline & 15 & $8.8 \mathrm{a}-\mathrm{d}$ & $9.8 \mathrm{a}$ & $9.2 \mathrm{a}-\mathrm{d}$ & $9.3 \mathrm{a}$ \\
\hline \multirow{3}{*}{ Medium } & 5 & $7.0 \mathrm{~g}$ & $8.1 \mathrm{c}-\mathrm{g}$ & $8.1 \mathrm{c}-\mathrm{g}$ & $7.7 \mathrm{~b}$ \\
\hline & 10 & $7.9 \mathrm{c}-\mathrm{g}$ & $8.1 \mathrm{c}-\mathrm{g}$ & $8.1 \mathrm{c}-\mathrm{g}$ & $8.0 \mathrm{~b}$ \\
\hline & 15 & $8.3 \mathrm{c}-\mathrm{g}$ & $9.7 \mathrm{ab}$ & $9.2 \mathrm{a}-\mathrm{d}$ & $9.1 \mathrm{a}$ \\
\hline \multirow{3}{*}{ Large } & 5 & $7.6 \mathrm{e}-\mathrm{g}$ & $8.5 \mathrm{~b}-\mathrm{f}$ & $7.9 \mathrm{~d}-\mathrm{g}$ & $8.0 \mathrm{~b}$ \\
\hline & 10 & $8.3 \mathrm{c}-\mathrm{g}$ & $8.0 \mathrm{c}-\mathrm{g}$ & $7.9 \mathrm{c}-\mathrm{g}$ & $8.1 \mathrm{~b}$ \\
\hline & 15 & $8.5 \mathrm{~b}-\mathrm{f}$ & $9.3 \mathrm{a}-\mathrm{c}$ & $9.9 \mathrm{a}$ & $9.2 \mathrm{a}$ \\
\hline \multicolumn{2}{|c|}{ fertilizers mean } & $7.9 \mathrm{~b}$ & $8.7 \mathrm{a}$ & $8.4 \mathrm{a}$ & \\
\hline \multicolumn{2}{|c|}{ Size } & $\mathrm{Siz}$ & fertilizer & & Size mean \\
\hline & mall & $8.0 \mathrm{bc}$ & $8.9 \mathrm{a}$ & $8.3 \mathrm{a}-\mathrm{c}$ & $8.4 \mathrm{a}$ \\
\hline & dium & $7.7 \mathrm{c}$ & $8.6 \mathrm{ab}$ & $8.4 \mathrm{a}-\mathrm{c}$ & $8.3 \mathrm{a}$ \\
\hline & arge & $8.1 \mathrm{bc}$ & $8.6 \mathrm{ab}$ & $8.5 \mathrm{ab}$ & $8.4 \mathrm{a}$ \\
\hline & epth & Dep & fertilize & lean & Depth mean \\
\hline & 5 & $7.3 \mathrm{c}$ & $8.4 \mathrm{~b}$ & $7.9 \mathrm{~b}$ & $7.9 \mathrm{~b}$ \\
\hline & 10 & $8.0 \mathrm{~b}$ & $8.1 \mathrm{~b}$ & $8.0 \mathrm{~b}$ & $8.0 \mathrm{~b}$ \\
\hline & 15 & $8.5 \mathrm{~b}$ & $9.6 \mathrm{a}$ & $9.4 \mathrm{a}$ & $9.2 \mathrm{a}$ \\
\hline
\end{tabular}

Means followed by similar letters within factors or their interactions are not significantly different according to DMRT (1955), at 5\% probability. 
In the interactions of seed sizes with fertilization, the large seeds with $(75$ and $150 \mathrm{~kg}$ $\left.\mathrm{P}_{2} \mathrm{O}_{5} . \mathrm{ha}^{-1}\right)$ gave the highest number of pods/ plant at Erbil, and decreased significantly with $\left(0 \mathrm{~kg} \mathrm{P}_{2} \mathrm{O}_{5}\right.$. ha- $\left.\mathrm{h}^{-1}\right)$ at Mosul the highest number of pods / plant was recorded in small seeds with $\left(150 \mathrm{~kg} \mathrm{P}_{2} \mathrm{O}_{5} . \mathrm{ha}^{-1}\right)$ level. The lowest number of pods / plant resulted from the medium size seeds without fertilization, concerning of depth and fertilization, the second sown at $(10 \mathrm{~cm})$ depth with all levels of fertilization, surpassed this character significantly at both locations. In the case of triple interaction it was noticed that the number of pods / plant increased at $(10 \mathrm{~cm})$ depth with all level fertilization, regardless of the seed sizes, this results show that $(10 \mathrm{~cm})$ depth and phosphate fertilization was superior comparing with other interaction.

Number of seeds / pod:

The data in table (5) shows no significant differences in the number of seeds / pods between seed sizes at both sites, similar results achieved by Idris (2008) and Mekkei (2014). The highest number of seeds / pod was observed at Erbil for the plants sown at $(15 \mathrm{~cm})$ depth $(6.64$ seeds / pod), which was not differ significantly from the depth $(5 \mathrm{~cm})$ as it gave $(6.46$ seeds / pod), while at Mosul site there is no differences in number of seeds / pod between different depths. The second level of fertilization at both sites surpassed significantly number of seeds / pod comparing with the other levels and gave 6.54 and 6.37 seed / pod at Erbil and Mosul respectively, this corresponds with Huthily and al-Hassani (2014); Sarkar et al (2017). The interaction of seed sizes and sowing depths was significantly higher for the three sizes at (5 and $15 \mathrm{~cm}$ ) depth at Erbil, the results were resemble to Mosul, and this is in consistent with the results of Singh et al (2010). The highest number of seeds / pods achieved for the second fertilization level $\left(75 \mathrm{~kg} \mathrm{P}_{2} \mathrm{O}_{5} . \mathrm{ha}^{-1}\right)$ with all seed sizes at both sites. The highest number of seeds / pod was recorded at $(15 \mathrm{~cm})$ depth with $\left(75 \mathrm{~kg} \mathrm{P}_{2} \mathrm{O}_{5}\right.$. $\left.\mathrm{ha}^{-1}\right)$ at Erbil. At Mosul the plants fertilized with $\left(75 \mathrm{~kg} \mathrm{P}_{2} \mathrm{O}_{5}\right.$. ha $\left.{ }^{-1}\right)$ at all depths gave the highest number of seeds / pod. The second order interaction gave highest number of seeds / pod for all seed sizes sown at $(15 \mathrm{~cm})$ depth and fertilized with $\left(75 \mathrm{~kg} \mathrm{P}_{2} \mathrm{O}_{5}\right.$. $\mathrm{ha}^{-1}$ ), while the no. seeds / pod was increased ( 7.13 seeds / pod) at Erbil location. While at Mosul the highest number of seeds / pod was obtained $(5 \mathrm{~cm})$ depth with medium seed size and $\left(150 \mathrm{~kg} \mathrm{P}_{2} \mathrm{O}_{5} . \mathrm{ha}^{-1}\right)$. In general it was noticed that flowering fertility was increased by adding super phosphate either in the second or third level of fertilization.

100 seed weight $(\mathrm{gm})$.

Table (6) revealed to no significant differences in the 100 seeds weight (gm) between seed sizes at both sites, this is in consistent with Idris (2008). While 100 seed weight surpassed significantly at $(15 \mathrm{~cm})$ depth comparing with other depths, the mean of 100 seed weight was (153.61gm) and (151.28g) at Erbil and Mosul respectively, these results are similar to that of Al-Anbari et al (2010). The two levels of fertilization (75 and $150 \mathrm{~kg} \mathrm{P}_{2} \mathrm{O}_{5} . \mathrm{ha}^{-1}$ ) have a positive significant effect on this characters comparing with (zero $\mathrm{kg} \mathrm{P}_{2} \mathrm{O}_{5}$. ha ${ }^{-1}$ ), even though three is no significant differences between the two levels. This is similar to Issa results (2009); Hashemabadi (2013); Huthily and al-Hassani (2014); Kubure et al (2016) and Sarkar et al (2017). 
Table (4): Effect of seed size, sowing depth, phosphorus fertilization and their interaction on number of pods /plants.

\begin{tabular}{|c|c|c|c|c|c|}
\hline \multicolumn{6}{|c|}{ Erbil location } \\
\hline \multirow{3}{*}{ Seed size } & \multirow{3}{*}{$\begin{array}{c}\text { Sowing } \\
\text { depth }(\mathrm{cm})\end{array}$} & \multicolumn{3}{|c|}{ phosphorus fertilizers rate } & \multirow{3}{*}{$\begin{array}{c}\text { Size X } \\
\text { Depth mean }\end{array}$} \\
\hline & & 0 & 75 & 150 & \\
\hline & & \multicolumn{3}{|c|}{ size, depth and fertilizers } & \\
\hline \multirow{3}{*}{ Small } & 5 & $8.5 \mathrm{hi}$ & $9.2 \mathrm{e}-\mathrm{g}$ & $9.0 \mathrm{e}-\mathrm{h}$ & $8.9 \mathrm{c}$ \\
\hline & 10 & $10.3 \mathrm{a}$ & $10.4 \mathrm{a}$ & $10.2 \mathrm{ab}$ & $10.3 \mathrm{a}$ \\
\hline & 15 & $9.1 \mathrm{e}-\mathrm{h}$ & $9.4 \mathrm{~d}-\mathrm{g}$ & $9.5 \mathrm{c}-\mathrm{f}$ & $9.3 \mathrm{~b}$ \\
\hline \multirow{3}{*}{ Medium } & 5 & $8.8 \mathrm{f}-\mathrm{i}$ & $8.7 \mathrm{~g}-\mathrm{i}$ & $9.3 \mathrm{~d}-\mathrm{g}$ & $8.9 \mathrm{c}$ \\
\hline & 10 & $10.5 \mathrm{a}$ & $10.1 \mathrm{a}-\mathrm{d}$ & $10.7 \mathrm{a}$ & $10.4 \mathrm{a}$ \\
\hline & 15 & $9.6 \mathrm{~b}-\mathrm{e}$ & $9.6 \mathrm{~b}-\mathrm{e}$ & $9.4 \mathrm{~d}-\mathrm{g}$ & $9.5 \mathrm{~b}$ \\
\hline \multirow{3}{*}{ Large } & 5 & $8.2 \mathrm{i}$ & $9.2 \mathrm{e}-\mathrm{g}$ & $9.2 \mathrm{e}-\mathrm{h}$ & $8.8 \mathrm{c}$ \\
\hline & 10 & $10.2 \mathrm{a}-\mathrm{c}$ & $10.7 \mathrm{a}$ & $10.6 \mathrm{a}$ & $10.5 \mathrm{a}$ \\
\hline & 15 & $9.0 \mathrm{e}-\mathrm{h}$ & $9.5 b-f$ & $9.5 \mathrm{~b}-\mathrm{f}$ & $9.3 \mathrm{~b}$ \\
\hline \multicolumn{2}{|c|}{ Fertilizers mean } & $9.3 \mathrm{~b}$ & $9.6 \mathrm{a}$ & $9.7 \mathrm{a}$ & \\
\hline \multicolumn{2}{|c|}{ Size } & \multicolumn{3}{|c|}{ Size $X$ fertilizers mean } & Size mean \\
\hline \multicolumn{2}{|c|}{ Small } & $9.3 \mathrm{bc}$ & $9.7 \mathrm{ab}$ & $9.5 \mathrm{ab}$ & $9.5 \mathrm{a}$ \\
\hline \multicolumn{2}{|c|}{ Medium } & $9.6 \mathrm{ab}$ & $9.4 \mathrm{a}-\mathrm{c}$ & $9.8 \mathrm{a}$ & $9.6 \mathrm{a}$ \\
\hline \multicolumn{2}{|c|}{ Large } & $9.1 \mathrm{c}$ & $9.8 \mathrm{a}$ & $9.7 \mathrm{a}$ & $9.6 \mathrm{a}$ \\
\hline \multicolumn{2}{|c|}{ Depth } & \multicolumn{3}{|c|}{ Depth X fertilizers mean } & Depth mean \\
\hline \multicolumn{2}{|c|}{5} & $8.5 \mathrm{~d}$ & $9.0 \mathrm{c}$ & $9.1 \mathrm{bc}$ & $8.9 \mathrm{c}$ \\
\hline \multicolumn{2}{|c|}{10} & $10.3 \mathrm{a}$ & $10.4 \mathrm{a}$ & $10.5 \mathrm{a}$ & $10.4 \mathrm{a}$ \\
\hline \multicolumn{2}{|c|}{15} & $9.2 \mathrm{bc}$ & $9.5 \mathrm{~b}$ & $9.5 \mathrm{~b}$ & $9.4 \mathrm{~b}$ \\
\hline \multicolumn{6}{|c|}{ Mosul location } \\
\hline \multirow{3}{*}{ Small } & 5 & $7.8 \mathrm{f}-\mathrm{h}$ & $8.3 \mathrm{~b}-\mathrm{g}$ & $8.7 \mathrm{a}-\mathrm{f}$ & $8.2 \mathrm{~b}$ \\
\hline & 10 & $9.4 \mathrm{a}-\mathrm{d}$ & $9.1 \mathrm{a}-\mathrm{f}$ & $9.6 \mathrm{ab}$ & $9.3 \mathrm{a}$ \\
\hline & 15 & $8.1 \mathrm{~d}-\mathrm{g}$ & $8.6 \mathrm{a}-\mathrm{f}$ & $8.7 \mathrm{a}-\mathrm{f}$ & $8.5 \mathrm{~b}$ \\
\hline \multirow{3}{*}{ Medium } & 5 & $6.9 \mathrm{~h}$ & $8.1 \mathrm{~d}-\mathrm{g}$ & $8.9 \mathrm{a}-\mathrm{f}$ & $7.9 \mathrm{~b}$ \\
\hline & 10 & 9.1 a-e & $9.4 \mathrm{a}-\mathrm{d}$ & $9.6 \mathrm{ab}$ & $9.3 \mathrm{a}$ \\
\hline & 15 & $8.8 \mathrm{a}-\mathrm{f}$ & 8.6 a-f & $8.2 \mathrm{~d}-\mathrm{g}$ & $8.5 \mathrm{~b}$ \\
\hline \multirow{3}{*}{ Large } & 5 & $7.2 \mathrm{gh}$ & 8.8 a-f & $8.4 \mathrm{~b}-\mathrm{g}$ & $8.1 \mathrm{~b}$ \\
\hline & 10 & $9.8 \mathrm{a}$ & $9.5 \mathrm{a}-\mathrm{c}$ & $9.6 \mathrm{ab}$ & $9.6 \mathrm{a}$ \\
\hline & 15 & $8.5 \mathrm{a}-\mathrm{f}$ & $8.7 \mathrm{a}-\mathrm{f}$ & 7.9 e-h & $8.3 \mathrm{~b}$ \\
\hline \multicolumn{2}{|c|}{ fertilizers mean } & $8.4 \mathrm{~b}$ & $8.8 \mathrm{a}$ & $8.8 \mathrm{a}$ & \\
\hline \multicolumn{2}{|c|}{ Size } & & fertilize & $\operatorname{an}$ & Size mean \\
\hline & hall & $8.4 \mathrm{ab}$ & $8.6 \mathrm{ab}$ & $9.0 \mathrm{a}$ & $8.7 \mathrm{a}$ \\
\hline & lium & $8.2 \mathrm{~b}$ & $8.7 \mathrm{ab}$ & $8.9 \mathrm{ab}$ & $8.6 \mathrm{a}$ \\
\hline & rge & $8.5 \mathrm{ab}$ & $9.0 \mathrm{a}$ & $8.6 \mathrm{a}$ & $8.7 \mathrm{a}$ \\
\hline & pth & Dep & fertilize & ean & Depth mean \\
\hline & 5 & $7.3 \mathrm{c}$ & $8.4 \mathrm{~b}$ & $8.7 \mathrm{~b}$ & $8.1 \mathrm{~b}$ \\
\hline & 0 & $9.4 \mathrm{a}$ & $9.3 \mathrm{a}$ & $9.6 \mathrm{a}$ & $9.4 \mathrm{a}$ \\
\hline & 5 & $8.5 \mathrm{~b}$ & $8.6 \mathrm{~b}$ & $8.2 \mathrm{~b}$ & $8.4 \mathrm{~b}$ \\
\hline
\end{tabular}

Means followed by similar letters within factors or their interactions are not significantl different according to DMRT (1955), at 5\% probability. 
All seed sizes sowing at $(15 \mathrm{~cm})$ surpassed significantly depths in 100 seed weight at both location. All sizes of seed fertilized with (75 and $150 \mathrm{~kg} \mathrm{P}_{2} \mathrm{O}_{5}$. ha $\mathrm{ha}^{-1}$ ) also surpassed for 100 seed weight comparing to $\left(0 \mathrm{~kg} \mathrm{P}_{2} \mathrm{O}_{5} . \mathrm{ha}^{-1}\right)$ at Erbil location, the results at Mosul were almost similar. The 100 seed weight surpassed significantly at $\left(15 \mathrm{~cm}\right.$ ) depth interfered with (zero and $75 \mathrm{~kg} \mathrm{P}_{2} \mathrm{O}_{5} . \mathrm{ha}^{-1}$ ) at Erbil location and with $\left(0,75\right.$ and $150 \mathrm{~kg} \mathrm{P}_{2} \mathrm{O}_{5}$. ha $\left.{ }^{-1}\right)$ at Mosul location. For the second order interaction, 100 seeds weight surpassed significantly at $(15 \mathrm{~cm})$ depth with all seed sizes and with all fertilization levels at both site.

Seed yield (gm /plant):

Table (7) revealed to no significant differences for seed yield regarding dissimilarity of seed sizes at both sites. This result in consistent with Idris (2008). The sowing depth $(15 \mathrm{~cm})$ gave significantly higher seed yield $(61.7$ and $61.5 \mathrm{gm} /$ plant) for Erbil and Mosul respectively, also the second and the third phosphate fertilization levels enhanced significantly this trait $(58.6,53.7 \mathrm{gm} /$ plant $)$ for Erbil and $(58.2,51.8 \mathrm{gm})$ for Mosul respectively, these results are in agreement with those of Issa (2009); Hashemabadi (2013); Huthily and al-Hassani (2014); Kubure et al (2016) and Sarkar et al (2017). The sowing depth at $(15 \mathrm{~cm})$ showed a significant increase in seed yield with all seed sizes. Also all sizes of seed surpassed significantly in seed yield by adding ( 75 and or $150 \mathrm{~kg} \mathrm{P}_{2} \mathrm{O}_{5} \mathrm{ha}^{-1}$ ) comparing with the other interaction at both locations. Seed yield (gm/plant) surpassed significantly by sowing at $(15 \mathrm{~cm})$ depth with all levels of fertilization, at $(10 \mathrm{~cm})$ depth with $(75$ and $150 \mathrm{~kg}$ $\left.\mathrm{P}_{2} \mathrm{O}_{5} \mathrm{ha}^{-1}\right)$ at Erbil. At Mosul the superiority was obvious when the seeds sowing at depth $(15 \mathrm{~cm})$ with all levels of fertilization. In triple interaction the highest value of the seed yield was recorded at all seed sizes sown at $(15 \mathrm{~cm})$ depth for all levels of fertilization at both site. The significant increase in seed yield due to the significant effect on yield components i.e. (number of pods / plant, number of seeds / pod and 100 seeds weight) (tables 4, 5 and 6).

Biological yield (gm /plant):

The biological yield was not affected significantly by the variation in seed sizes at both locations, (table 8), this in consistent with Mekkei (2014). The biological yield raised significantly at $(5 \mathrm{~cm})$ depth to $(156.7$ and $153.0 \mathrm{gm} /$ plant $)$ for Erbil and Mosul respectively. The third and second level of phosphate surpassed significantly the biological yield (157.5, $154.2 \mathrm{gm} /$ plant) for third level and (154.6, $152.0 \mathrm{gm}$ /plant) for second level at Erbil and Mosul respectively. These results agree with Kuure et al. (2016), The interaction between the two depths (5 and $15 \mathrm{~cm}$ ) with all seed sizes was significantly superior in biological yield. Also all sizes of seeds with the second and third fertilization levels surpassed significantly the biological yield and exceeded the rest interactions. The biological yield increased significantly at $(5 \mathrm{~cm})$ depth with $\left(150 \mathrm{~kg} \mathrm{P}_{2} \mathrm{O}_{5} \mathrm{ha}^{-1}\right)$ at both sites. The second order interaction at all sizes of seeds planted at depth $(5 \mathrm{~cm})$, and fertilized with $\left(150 \mathrm{~kg} \mathrm{P}_{2} \mathrm{O}_{5} \cdot \mathrm{ha}^{-1}\right)$ surpassed significantly biological yield comparing with the rest treatment combinations. 
Table (5) Effect of seed size, sowing depth, phosphorus fertilization and their interaction on number of seeds / pods.

\begin{tabular}{|c|c|c|c|c|c|}
\hline \multirow{4}{*}{ Seed size } & \multicolumn{5}{|c|}{ Erbil location } \\
\hline & \multirow{3}{*}{$\begin{array}{c}\text { Sowing } \\
\text { depth }(\mathrm{cm})\end{array}$} & \multicolumn{3}{|c|}{ phosphorus fertilizers rate } & \multirow{3}{*}{$\begin{array}{l}\text { Size } X \text { Depth } \\
\text { mean }\end{array}$} \\
\hline & & 0 & 75 & 150 & \\
\hline & & \multicolumn{3}{|c|}{ size, depth and fertilizers } & \\
\hline \multirow{3}{*}{ Small } & 5 & $5.9 \mathrm{e}-\mathrm{i}$ & $6.9 \mathrm{ab}$ & $6.6 \mathrm{a}-\mathrm{e}$ & $6.5 \mathrm{a}$ \\
\hline & 10 & $5.1 \mathrm{j}$ & $5.6 \mathrm{~g}-\mathrm{j}$ & $5.4 \mathrm{hij}$ & $5.4 \mathrm{~b}$ \\
\hline & 15 & $6.1 \mathrm{f}-\mathrm{h}$ & $7.1 \mathrm{a}$ & $6.1 \mathrm{~d}-\mathrm{h}$ & $6.4 \mathrm{a}$ \\
\hline \multirow{3}{*}{ Medium } & 5 & $5.6 \mathrm{~g}-\mathrm{j}$ & $7.0 \mathrm{ab}$ & $6.6 \mathrm{a}-\mathrm{e}$ & $6.4 \mathrm{a}$ \\
\hline & 10 & $5.8 \mathrm{f}-\mathrm{j}$ & $5.5 \mathrm{~g}-\mathrm{j}$ & $5.8 \mathrm{f}-\mathrm{j}$ & $5.7 \mathrm{~b}$ \\
\hline & 15 & $6.7 \mathrm{a}-\mathrm{d}$ & $7.1 \mathrm{a}$ & $6.4 \mathrm{~b}-\mathrm{f}$ & $6.7 \mathrm{a}$ \\
\hline \multirow{3}{*}{ Large } & 5 & $5.8 \mathrm{~g}-\mathrm{j}$ & $6.8 \mathrm{a}-\mathrm{c}$ & $6.6 \mathrm{a}-\mathrm{e}$ & $6.4 \mathrm{a}$ \\
\hline & 10 & $5.2 \mathrm{ij}$ & $5.5 \mathrm{~g}-\mathrm{j}$ & $5.5 \mathrm{~g}-\mathrm{j}$ & $5.4 \mathrm{~b}$ \\
\hline & 15 & $6.2 \mathrm{c}-\mathrm{g}$ & $7.1 \mathrm{a}$ & $6.7 \mathrm{a}-\mathrm{d}$ & $6.6 \mathrm{a}$ \\
\hline \multicolumn{2}{|c|}{ fertilizers mean } & $5.8 \mathrm{c}$ & $6.5 \mathrm{a}$ & $6.2 \mathrm{~b}$ & \\
\hline \multicolumn{2}{|c|}{ Size } & \multicolumn{3}{|c|}{ Size $\mathrm{X}$ fertilizers mean } & Size mean \\
\hline \multicolumn{2}{|c|}{ Small } & $5.7 \mathrm{c}$ & $6.5 \mathrm{a}$ & $6.0 \mathrm{bc}$ & $6.1 \mathrm{a}$ \\
\hline \multicolumn{2}{|c|}{ Medium } & $6.0 \mathrm{bc}$ & $6.5 \mathrm{a}$ & $6.3 \mathrm{ab}$ & $6.3 \mathrm{a}$ \\
\hline \multicolumn{2}{|c|}{ Large } & $5.7 \mathrm{c}$ & $6.5 \mathrm{a}$ & $6.2 \mathrm{ab}$ & $6.1 \mathrm{a}$ \\
\hline \multicolumn{2}{|c|}{ Depth } & \multicolumn{3}{|c|}{ Depth X fertilizers mean } & Depth mean \\
\hline \multicolumn{2}{|c|}{5} & $5.8 \mathrm{~d}$ & $6.9 \mathrm{ab}$ & $6.6 \mathrm{bc}$ & $6.4 \mathrm{a}$ \\
\hline \multicolumn{2}{|c|}{10} & $5.4 \mathrm{e}$ & $5.5 \mathrm{de}$ & $5.6 \mathrm{de}$ & $5.5 \mathrm{~b}$ \\
\hline \multicolumn{2}{|c|}{15} & $6.3 \mathrm{c}$ & $7.1 \mathrm{a}$ & $6.4 \mathrm{c}$ & $6.6 \mathrm{a}$ \\
\hline \multicolumn{6}{|c|}{ Mosul location } \\
\hline \multirow{3}{*}{ Small } & 5 & $5.4 \mathrm{f}-\mathrm{i}$ & $6.4 \mathrm{a}-\mathrm{e}$ & $6.4 \mathrm{a}-\mathrm{d}$ & $6.1 \mathrm{ab}$ \\
\hline & 10 & $5.4 \mathrm{f}-\mathrm{i}$ & $6.2 \mathrm{a}-\mathrm{h}$ & $5.2 \mathrm{hi}$ & $5.6 \mathrm{~b}$ \\
\hline & 15 & $6.0 \mathrm{~b}-\mathrm{i}$ & $6.6 \mathrm{ab}$ & $5.4 \mathrm{e}-\mathrm{i}$ & $6.0 \mathrm{ab}$ \\
\hline \multirow{3}{*}{ Medium } & 5 & $5.0 \mathrm{i}$ & $6.5 \mathrm{a}-\mathrm{c}$ & $7.1 \mathrm{a}$ & $6.2 \mathrm{a}$ \\
\hline & 10 & $6.1 \mathrm{a}-\mathrm{h}$ & $6.2 \mathrm{a}-\mathrm{g}$ & $5.1 \mathrm{i}$ & $5.8 \mathrm{ab}$ \\
\hline & 15 & $5.5 \mathrm{~d}-\mathrm{i}$ & $6.1 \mathrm{a}-\mathrm{h}$ & $5.8 \mathrm{~b}-\mathrm{i}$ & $5.8 \mathrm{ab}$ \\
\hline \multirow{3}{*}{ Large } & 5 & $5.5 \mathrm{~d}-\mathrm{i}$ & $6.3 \mathrm{a}-\mathrm{f}$ & $6.1 \mathrm{a}-\mathrm{h}$ & $6.0 \mathrm{ab}$ \\
\hline & 10 & $6.6 \mathrm{ab}$ & $6.6 \mathrm{ab}$ & $5.3 \mathrm{~g}-\mathrm{i}$ & $6.2 \mathrm{a}$ \\
\hline & 15 & $5.6 \mathrm{c}-\mathrm{i}$ & $6.1 \mathrm{a}-\mathrm{h}$ & $6.2 \mathrm{a}-\mathrm{h}$ & $5.9 \mathrm{ab}$ \\
\hline \multicolumn{2}{|c|}{ fertilizers mean } & $5.7 \mathrm{~b}$ & $6.3 \mathrm{a}$ & $5.8 \mathrm{~b}$ & \\
\hline \multicolumn{2}{|c|}{ Size } & Siz & fertiliz & mean & Size mean \\
\hline & nall & $5.6 \mathrm{c}$ & $6.4 \mathrm{a}$ & $5.7 \mathrm{c}$ & $5.9 \mathrm{a}$ \\
\hline & dium & $5.5 \mathrm{c}$ & $5.5 \mathrm{ab}$ & $6.0 \mathrm{a}-\mathrm{c}$ & $5.9 \mathrm{a}$ \\
\hline & $\operatorname{arge}$ & $5.9 \mathrm{a}-\mathrm{c}$ & $6.3 \mathrm{ab}$ & $5.9 \mathrm{bc}$ & $6.0 \mathrm{a}$ \\
\hline & epth & Dep & $\mathrm{K}$ fertiliz & mean & Depth mean \\
\hline & 5 & $5.3 \mathrm{~cd}$ & $6.4 \mathrm{a}$ & $6.5 \mathrm{a}$ & $6.1 \mathrm{a}$ \\
\hline & 10 & $6.0 \mathrm{ab}$ & $6.3 \mathrm{a}$ & $5.2 \mathrm{~d}$ & $5.8 \mathrm{a}$ \\
\hline & 15 & $5.7 \mathrm{~b}-\mathrm{d}$ & $6.3 \mathrm{a}$ & $5.8 \mathrm{bc}$ & $5.9 \mathrm{a}$ \\
\hline
\end{tabular}

Means followed by similar letters within factors or their interactions are not significantl different according to DMRT (1955), at 5\% probability. 
Table (6): Effect of seed size, sowing depth, phosphorus fertilization and their interaction on 100 seed weight (gm).

\begin{tabular}{|c|c|c|c|c|c|}
\hline \multirow[t]{3}{*}{ Seed size } & \multirow{3}{*}{$\begin{array}{c}\text { Sowing } \\
\text { depth }(\mathrm{cm})\end{array}$} & \multicolumn{3}{|c|}{ phosphorus fertilizers rate } & \multirow{3}{*}{$\begin{array}{c}\text { Size X depth } \\
\text { mean }\end{array}$} \\
\hline & & 0 & 75 & 150 & \\
\hline & & \multicolumn{3}{|c|}{ size, depth and fertilizers } & \\
\hline \multirow[t]{3}{*}{ Small } & 5 & $77.7 \mathrm{~h}$ & $92.8 \mathrm{~g}$ & $96.4 \mathrm{~g}$ & $88.9 \mathrm{c}$ \\
\hline & 10 & $113.9 \mathrm{f}$ & $144.1 \mathrm{e}$ & $145.7 \mathrm{de}$ & $134.6 \mathrm{~b}$ \\
\hline & 15 & $157.9 \mathrm{a}$ & $154.1 \mathrm{a}-\mathrm{c}$ & $151.2 \mathrm{a}-\mathrm{e}$ & $154.4 \mathrm{a}$ \\
\hline \multirow[t]{3}{*}{ Medium } & 5 & $80.2 \mathrm{~h}$ & $93.1 \mathrm{~g}$ & $96.7 \mathrm{~g}$ & $90.0 \mathrm{c}$ \\
\hline & 10 & $115.7 \mathrm{f}$ & $144.1 \mathrm{e}$ & $148.7 \mathrm{~b}-\mathrm{e}$ & $136.2 \mathrm{~b}$ \\
\hline & 15 & $155.4 \mathrm{ab}$ & $152.9 \mathrm{a}-\mathrm{d}$ & 150.9 a-e & $153.1 \mathrm{a}$ \\
\hline \multirow[t]{3}{*}{ Large } & 5 & $80.1 \mathrm{~h}$ & $93.6 \mathrm{~g}$ & $97.9 \mathrm{~g}$ & $90.6 \mathrm{c}$ \\
\hline & 10 & $112.6 \mathrm{f}$ & $143.9 \mathrm{e}$ & $147.0 \mathrm{c}-\mathrm{e}$ & $134.5 \mathrm{~b}$ \\
\hline & 15 & $153.9 \mathrm{a}-\mathrm{c}$ & $154.6 \mathrm{a}-\mathrm{c}$ & $151.3 \mathrm{a}-\mathrm{e}$ & $153.3 \mathrm{a}$ \\
\hline \multicolumn{2}{|c|}{ fertilizers mean } & $116.4 \mathrm{~b}$ & $130.3 \mathrm{a}$ & $131.7 \mathrm{a}$ & \\
\hline \multicolumn{2}{|c|}{ Size } & \multicolumn{3}{|c|}{ Size $X$ fertilizers mean } & Size mean \\
\hline \multicolumn{2}{|c|}{ Small } & $116.5 \mathrm{~b}$ & $130.3 \mathrm{a}$ & $131.1 \mathrm{a}$ & $126.0 \mathrm{a}$ \\
\hline \multicolumn{2}{|c|}{ Medium } & $117.1 \mathrm{~b}$ & $130.0 \mathrm{a}$ & $132.1 \mathrm{a}$ & $126.4 \mathrm{a}$ \\
\hline \multicolumn{2}{|c|}{ Large } & $115.5 \mathrm{~b}$ & $130.7 \mathrm{a}$ & $132.1 \mathrm{a}$ & $126.1 \mathrm{a}$ \\
\hline \multicolumn{2}{|c|}{ Depth } & \multicolumn{3}{|c|}{ Depth X fertilizers mean } & Depth mean \\
\hline \multicolumn{2}{|c|}{5} & $79.3 \mathrm{~g}$ & $93.1 \mathrm{f}$ & $97.0 \mathrm{f}$ & $89.8 \mathrm{c}$ \\
\hline \multicolumn{2}{|c|}{10} & $114.1 \mathrm{e}$ & $144.0 \mathrm{~d}$ & $147.1 \mathrm{~cd}$ & $135.1 \mathrm{~b}$ \\
\hline \multicolumn{2}{|c|}{15} & $155.7 \mathrm{a}$ & $153.9 \mathrm{ab}$ & $151.1 \mathrm{bc}$ & $153.6 \mathrm{a}$ \\
\hline \multicolumn{6}{|c|}{ Mosul location } \\
\hline \multirow[t]{3}{*}{ Small } & 5 & $74.4 \mathrm{f}$ & $84.6 \mathrm{e}$ & $85.2 \mathrm{e}$ & $81.4 \mathrm{~d}$ \\
\hline & 10 & $102.8 \mathrm{~cd}$ & $106.1 \mathrm{bc}$ & $104.2 \mathrm{~cd}$ & $104.4 \mathrm{bc}$ \\
\hline & 15 & $151.7 \mathrm{a}$ & $152.7 \mathrm{a}$ & $150.7 \mathrm{a}$ & $151.7 \mathrm{a}$ \\
\hline \multirow[t]{3}{*}{ Medium } & 5 & $74.2 \mathrm{f}$ & $85.7 \mathrm{e}$ & $84.5 \mathrm{e}$ & $81.5 \mathrm{~d}$ \\
\hline & 10 & $103.4 \mathrm{~cd}$ & $108.1 \mathrm{~b}$ & $105.0 \mathrm{~b}-\mathrm{d}$ & $105.5 \mathrm{~b}$ \\
\hline & 15 & $151.2 \mathrm{a}$ & $151.7 \mathrm{a}$ & $150.5 \mathrm{a}$ & $151.1 \mathrm{a}$ \\
\hline \multirow[t]{3}{*}{ Large } & 5 & $74.1 \mathrm{f}$ & $83.9 \mathrm{e}$ & $85.6 \mathrm{e}$ & $81.2 \mathrm{~d}$ \\
\hline & 10 & $102.0 \mathrm{~d}$ & $103.6 \mathrm{~cd}$ & $105.3 \mathrm{~b}-\mathrm{d}$ & $103.6 \mathrm{c}$ \\
\hline & 15 & $151.5 \mathrm{a}$ & $151.0 \mathrm{a}$ & $150.3 \mathrm{a}$ & $150.9 \mathrm{a}$ \\
\hline \multicolumn{2}{|c|}{ fertilizers mean } & $109.5 \mathrm{~b}$ & $114.1 \mathrm{a}$ & $113.5 \mathrm{a}$ & \\
\hline \multicolumn{2}{|c|}{ Size } & \multicolumn{3}{|c|}{ Size X fertilizers mean } & Size mean \\
\hline & nall & $109.6 \mathrm{c}$ & $114.5 \mathrm{ab}$ & $113.4 \mathrm{ab}$ & $112.5 \mathrm{a}$ \\
\hline & dium & $109.6 \mathrm{c}$ & $115.2 \mathrm{a}$ & $113.4 \mathrm{ab}$ & $112.7 \mathrm{a}$ \\
\hline & irge & $109.2 \mathrm{c}$ & $112.8 \mathrm{~b}$ & $113.7 \mathrm{ab}$ & $111.9 \mathrm{a}$ \\
\hline & pth & Dept & $\mathrm{X}$ fertilizer & mean & Depth mean \\
\hline & 5 & $74.2 \mathrm{e}$ & $84.7 \mathrm{~d}$ & $85.1 \mathrm{~d}$ & $81.3 \mathrm{c}$ \\
\hline & 10 & $102.7 \mathrm{c}$ & $105.9 \mathrm{~b}$ & $104.8 \mathrm{~b}$ & $104.5 \mathrm{~b}$ \\
\hline & 5 & $151.4 \mathrm{a}$ & $151.8 \mathrm{a}$ & $150.5 \mathrm{a}$ & $151.2 \mathrm{a}$ \\
\hline
\end{tabular}

Means followed by similar letters within factors or their interactions are not significantly different according to DMRT (1955), at 5\% probability. 
Table (7) Effect of seed size, sowing depth, phosphorus fertilization and their interaction on seed yield (gm /Plant).

\begin{tabular}{|c|c|c|c|c|c|}
\hline \multirow{4}{*}{ Seed size } & \multicolumn{5}{|c|}{ Erbil location } \\
\hline & \multirow{3}{*}{$\begin{array}{c}\text { Sowing } \\
\text { depth }(\mathrm{cm})\end{array}$} & \multicolumn{3}{|c|}{ phosphorus fertilizers rate } & \multirow{3}{*}{$\begin{array}{c}\text { Size X Depth } \\
\text { mean }\end{array}$} \\
\hline & & 0 & 75 & 150 & \\
\hline & & \multicolumn{3}{|c|}{ size, depth and fertilizers } & \\
\hline \multirow[t]{3}{*}{ Small } & 5 & $37.4 \mathrm{c}$ & $51.0 \mathrm{~b}$ & $50.6 \mathrm{~b}$ & $46.3 \mathrm{~d}$ \\
\hline & 10 & $53.2 \mathrm{~b}$ & $63.5 \mathrm{a}$ & $61.1 \mathrm{a}$ & $59.3 \mathrm{c}$ \\
\hline & 15 & $61.5 \mathrm{a}$ & $62.5 \mathrm{a}$ & $62.1 \mathrm{a}$ & $62.0 \mathrm{a}$ \\
\hline \multirow[t]{3}{*}{ Medium } & 5 & $38.4 \mathrm{c}$ & $51.0 \mathrm{~b}$ & $51.5 \mathrm{~b}$ & $46.9 \mathrm{~d}$ \\
\hline & 10 & $54.4 \mathrm{~b}$ & $62.1 \mathrm{a}$ & $63.4 \mathrm{a}$ & $60.0 \mathrm{a}-\mathrm{c}$ \\
\hline & 15 & $61.9 \mathrm{a}$ & $61.6 \mathrm{a}$ & $61.3 \mathrm{a}$ & $61.6 \mathrm{ab}$ \\
\hline \multirow[t]{3}{*}{ Large } & 5 & $37.3 \mathrm{c}$ & $51.0 \mathrm{~b}$ & $50.8 \mathrm{~b}$ & $46.4 \mathrm{~d}$ \\
\hline & 10 & $54.1 \mathrm{~b}$ & $62.6 \mathrm{a}$ & $62.1 \mathrm{a}$ & $59.6 \mathrm{bc}$ \\
\hline & 15 & $61.0 \mathrm{a}$ & $61.8 \mathrm{a}$ & $61.2 \mathrm{a}$ & $61.3 \mathrm{a}-\mathrm{c}$ \\
\hline \multicolumn{2}{|c|}{ fertilizers mean } & $51.0 \mathrm{~b}$ & $58.6 \mathrm{a}$ & $58.2 \mathrm{a}$ & \\
\hline \multicolumn{2}{|c|}{ Size } & \multicolumn{3}{|c|}{ Size $\mathrm{X}$ fertilizers mean } & Size mean \\
\hline \multicolumn{2}{|c|}{ Small } & $50.7 \mathrm{~b}$ & $59.030 \mathrm{a}$ & $58.002 \mathrm{a}$ & $55.9341 \mathrm{a}$ \\
\hline \multicolumn{2}{|c|}{ Medium } & $51.5 \mathrm{~b}$ & $58.278 \mathrm{a}$ & $58.801 \mathrm{a}$ & $56.2219 \mathrm{a}$ \\
\hline \multicolumn{2}{|c|}{ Large } & $50.8 \mathrm{~b}$ & $58.513 \mathrm{a}$ & $58.083 \mathrm{a}$ & $55.8233 \mathrm{a}$ \\
\hline \multicolumn{2}{|c|}{ Depth } & \multicolumn{3}{|c|}{ Depth X fertilizers mean } & Depth mean \\
\hline \multicolumn{2}{|c|}{5} & $37.7 \mathrm{~d}$ & $51.0 \mathrm{c}$ & $51.0 \mathrm{c}$ & $46.6 \mathrm{c}$ \\
\hline \multicolumn{2}{|c|}{10} & $53.9 \mathrm{~b}$ & $62.7 \mathrm{a}$ & $62.2 \mathrm{a}$ & $59.6 \mathrm{~b}$ \\
\hline \multicolumn{2}{|c|}{15} & $37.7 \mathrm{~d}$ & $62.0 \mathrm{a}$ & $61.5 \mathrm{a}$ & $61.7 \mathrm{a}$ \\
\hline \multicolumn{6}{|c|}{ Mosul location } \\
\hline \multirow[t]{3}{*}{ Small } & 5 & $28.9 \mathrm{k}$ & $40.3 \mathrm{j}$ & $50.6 \mathrm{~b}$ & $37.9 \mathrm{c}$ \\
\hline & 10 & $51.5 \mathrm{f}-\mathrm{i}$ & $56.3 \mathrm{~b}-\mathrm{g}$ & $50.0 \mathrm{~g}-\mathrm{i}$ & $52.6 \mathrm{~b}$ \\
\hline & 15 & $62.0 \mathrm{ab}$ & $61.4 \mathrm{a}-\mathrm{c}$ & $60.9 \mathrm{a}-\mathrm{d}$ & $61.4 \mathrm{a}$ \\
\hline \multirow[t]{3}{*}{ Medium } & 5 & $23.8 \mathrm{k}$ & $40.8 \mathrm{j}$ & $46.5 \mathrm{hij}$ & $37.0 \mathrm{c}$ \\
\hline & 10 & $53.4 \mathrm{~d}-\mathrm{h}$ & 57.6 a-e & $49.7 \mathrm{~g}-\mathrm{i}$ & $53.5 \mathrm{~b}$ \\
\hline & 15 & $61.8 \mathrm{ab}$ & $62.3 \mathrm{ab}$ & $60.9 \mathrm{a}-\mathrm{d}$ & $61.6 \mathrm{a}$ \\
\hline \multirow[t]{3}{*}{ Large } & 5 & $27.1 \mathrm{k}$ & $41.4 \mathrm{j}$ & $42.2 \mathrm{j}$ & $36.9 \mathrm{c}$ \\
\hline & 10 & $54.1 \mathrm{c}-\mathrm{g}$ & 59.0 a-e & $52.2 \mathrm{e}-\mathrm{h}$ & $55.1 \mathrm{~b}$ \\
\hline & 15 & $60.3 \mathrm{a}-\mathrm{d}$ & $64.2 \mathrm{a}$ & $59.8 \mathrm{a}-\mathrm{d}$ & $61.4 \mathrm{a}$ \\
\hline \multicolumn{2}{|c|}{ fertilizers mean } & $47.0 \mathrm{~b}$ & $53.7 \mathrm{a}$ & $51.8 \mathrm{a}$ & \\
\hline \multicolumn{2}{|c|}{ Size } & & $\mathrm{X}$ fertilize & mean & Size mean \\
\hline & nall & $47.5 \mathrm{~b}$ & $52.6 \mathrm{a}$ & $51.8 \mathrm{a}$ & $50.6 \mathrm{a}$ \\
\hline M & dium & $46.3 \mathrm{~b}$ & $53.5 \mathrm{a}$ & $52.3 \mathrm{a}$ & $50.7 \mathrm{a}$ \\
\hline & rge & $47.2 \mathrm{~b}$ & $54.9 \mathrm{a}$ & $51.4 \mathrm{a}$ & $51.1 \mathrm{a}$ \\
\hline & epth & Dep & $\mathrm{X}$ fertiliz & mean & Depth mean \\
\hline & 5 & $26.6 \mathrm{e}$ & $40.8 \mathrm{~d}$ & $44.4 \mathrm{~d}$ & $37.2 \mathrm{c}$ \\
\hline & 10 & $53.0 \mathrm{c}$ & $57.6 \mathrm{~b}$ & $50.6 \mathrm{c}$ & $53.7 \mathrm{~b}$ \\
\hline & 15 & $61.3 \mathrm{ab}$ & $62.6 \mathrm{a}$ & $60.5 \mathrm{ab}$ & $61.5 \mathrm{a}$ \\
\hline
\end{tabular}

Means followed by similar letters within factors or their interactions are not significantly different according to DMRT (1955), at 5\% probability. 
Harvest index (HI) (\%).

The data in table (9) refer to no significant effect of seed sizes in (HI) at both site. This result in consistent with Mekkei (2014). Sowing at $(10 \mathrm{~cm})$ depth gave higher (HI) at Erbil $(41.55 \%)$ in consistent, while sowing at $(15 \mathrm{~cm})$ depth gave the higher (HI) at Mosul (41.10\%). The (HI) surpassed with the second and third level of $\left(\mathrm{P}_{2} \mathrm{O}_{5}\right)$ at Erbil and for the second level of fertilization at Mosul. The interaction between seed size and sowing depths showed that small, medium and large seeds were significantly surpassed in $(10$ and $15 \mathrm{~cm})$ depth at Erbil, while $(15 \mathrm{~cm})$ depth with all seed sizes was best at mosul. All sizes of seeds fertilized with (75 and $150 \mathrm{~kg}$ $\mathrm{P}_{2} \mathrm{O}_{5} h^{-1}$ ) exceeded other interactions for this trait. The highest (HI) was obtained from $(10 \mathrm{~cm})$ depth with the second and third fertilization levels at Erbil i.e. (75 and $\left.150 \mathrm{~kg} \mathrm{P}_{2} \mathrm{O}_{5} \mathrm{ha}^{-1}\right)$, while at Mosul the $(15 \mathrm{~cm})$ depth with all levels of fertilization, and $(10 \mathrm{~cm})$ depth with $\left(75 \mathrm{~kg} \mathrm{P}_{2} \mathrm{O}_{5} . \mathrm{ha}^{-1}\right)$ surpassed the remaining interaction this trait. The second order interaction was significant for (HI) at both site. In general, the $(10 \mathrm{~cm})$ depth with (75 and $150 \mathrm{~kg} \mathrm{P}_{2} \mathrm{O}_{5} \mathrm{ha}^{-1}$ ) and with all seed sizes significantly than superior the rest interactions for (HI) at Erbil, while at Mosul the $(15 \mathrm{~cm})$ depth with all seed sizes and all fertilization levels was greater. The highest (HI) was recorded for the medium seed grown at $(15 \mathrm{~cm})$ depth without fertilization $(42.35 \%)$.

We can concluded that there is no obvious effect of seed sizes on most studied traits, while the $(10$ and $15 \mathrm{~cm})$ depths positively affect most yield traits, and most traits were positively affected while increasing the amount of fertilizer, especially at (10 and $15 \mathrm{~cm})$ depths as the moisture is more available than in these depths of the (5cm) depth. 
Table (8): Effect of seed size, sowing depth, phosphorus fertilization and their interaction on biological yield (gm /plant).

\begin{tabular}{|c|c|c|c|c|c|}
\hline \multirow{4}{*}{ seed size } & \multicolumn{5}{|c|}{ Erbil location } \\
\hline & \multirow{3}{*}{$\begin{array}{c}\text { Sowing } \\
\text { depth }(\mathrm{cm})\end{array}$} & \multicolumn{3}{|c|}{ phosphorus fertilizers rate } & \multirow{3}{*}{$\begin{array}{l}\text { Size X Depth } \\
\text { mean }\end{array}$} \\
\hline & & 0 & 75 & 150 & \\
\hline & & \multicolumn{3}{|c|}{ size, depth and fertilizers } & \\
\hline \multirow{3}{*}{ Small } & 5 & $129.0 \mathrm{f}$ & $164.5 \mathrm{c}$ & $179.1 \mathrm{a}$ & $157.6 \mathrm{a}$ \\
\hline & 10 & $144.3 \mathrm{de}$ & $143.9 \mathrm{de}$ & $141.7 \mathrm{e}$ & $143.3 \mathrm{~b}$ \\
\hline & 15 & $151.6 \mathrm{de}$ & $153.7 \mathrm{~d}$ & $154.2 \mathrm{~d}$ & $153.2 \mathrm{a}$ \\
\hline \multirow{3}{*}{ Medium } & 5 & $126.5 \mathrm{f}$ & $167.5 \mathrm{bc}$ & $176.3 \mathrm{ab}$ & $156.8 \mathrm{a}$ \\
\hline & 10 & $143.7 \mathrm{de}$ & $143.7 \mathrm{de}$ & $143.3 \mathrm{de}$ & $143.6 \mathrm{~b}$ \\
\hline & 15 & $150.9 \mathrm{de}$ & $153.4 \mathrm{~d}$ & $152.0 \mathrm{de}$ & $152.1 \mathrm{a}$ \\
\hline \multirow{3}{*}{ Large } & 5 & $125.1 \mathrm{f}$ & $167.2 \mathrm{bc}$ & $174.7 \mathrm{ab}$ & $155.7 \mathrm{a}$ \\
\hline & 10 & $144.5 \mathrm{de}$ & $143.5 \mathrm{de}$ & $143.6 \mathrm{de}$ & $143.9 \mathrm{~b}$ \\
\hline & 15 & $151.0 \mathrm{de}$ & $153.9 \mathrm{~d}$ & $152.5 \mathrm{de}$ & $152.5 \mathrm{a}$ \\
\hline \multicolumn{2}{|c|}{ fertilizers mean } & $140.7 \mathrm{~b}$ & $154.6 \mathrm{a}$ & $157.5 \mathrm{a}$ & \\
\hline \multicolumn{2}{|c|}{ Size } & \multicolumn{3}{|c|}{ Size $X$ fertilizers mean } & Size mean \\
\hline \multicolumn{2}{|c|}{ Small } & $141.6 \mathrm{~b}$ & $154.1 \mathrm{a}$ & $158.3 \mathrm{a}$ & $151.3 \mathrm{a}$ \\
\hline \multicolumn{2}{|c|}{ Medium } & $140.4 \mathrm{~b}$ & $154.9 \mathrm{a}$ & $157.2 \mathrm{a}$ & $150.8 \mathrm{a}$ \\
\hline \multicolumn{2}{|c|}{ Large } & $140.2 \mathrm{~b}$ & $154.9 \mathrm{a}$ & $156.9 \mathrm{a}$ & $150.7 \mathrm{a}$ \\
\hline \multicolumn{2}{|c|}{ Depth } & \multicolumn{3}{|c|}{ Depth $X$ fertilizers mean } & Depth mean \\
\hline \multicolumn{2}{|c|}{5} & $126.9 \mathrm{e}^{\mathrm{t}}$ & $166.4 \mathrm{~b}$ & $176.7 \mathrm{a}$ & $156.7 \mathrm{a}$ \\
\hline \multicolumn{2}{|c|}{10} & $144.2 \mathrm{~d}$ & $143.7 \mathrm{~d}$ & $142.8 \mathrm{~d}$ & $143.6 \mathrm{c}$ \\
\hline \multicolumn{2}{|c|}{15} & $151.2 \mathrm{c}$ & $153.7 \mathrm{c}$ & $152.9 \mathrm{c}$ & $152.6 \mathrm{~b}$ \\
\hline \multicolumn{6}{|c|}{ Mosul location } \\
\hline \multirow{3}{*}{ Small } & 5 & $121.5 \mathrm{~g}$ & $164.4 \mathrm{ab}$ & $170.2 \mathrm{ab}$ & $152.0 \mathrm{a}$ \\
\hline & 10 & 140.9 ef & $141.2 \mathrm{~d}-\mathrm{f}$ & $141.7 \mathrm{c}-\mathrm{f}$ & $141.1 \mathrm{~b}$ \\
\hline & 15 & $146.4 \mathrm{c}-\mathrm{f}$ & $152.2 \mathrm{c}$ & $150.7 \mathrm{c}-\mathrm{e}$ & $149.7 \mathrm{a}$ \\
\hline \multirow{3}{*}{ Medium } & 5 & $123.4 \mathrm{~g}$ & $164.2 \mathrm{ab}$ & $173.3 \mathrm{a}$ & $153.6 \mathrm{a}$ \\
\hline & 10 & $140.0 \mathrm{ef}$ & $140.5 \mathrm{ef}$ & $140.5 \mathrm{ef}$ & $140.4 \mathrm{~b}$ \\
\hline & 15 & $145.9 \mathrm{c}-\mathrm{f}$ & $150.3 \mathrm{c}-\mathrm{f}$ & $149.1 \mathrm{c}-\mathrm{f}$ & $148.5 \mathrm{a}$ \\
\hline \multirow{3}{*}{ Large } & 5 & $125.8 \mathrm{~g}$ & $162.5 \mathrm{~b}$ & $171.6 \mathrm{ab}$ & $153.3 \mathrm{a}$ \\
\hline & 10 & $141.2 \mathrm{~d}-\mathrm{f}$ & $141.7 \mathrm{c}-\mathrm{f}$ & $139.4 \mathrm{f}$ & $140.7 \mathrm{~b}$ \\
\hline & 15 & $149.8 \mathrm{c}-\mathrm{f}$ & $151.0 \mathrm{c}-\mathrm{e}$ & $151.9 \mathrm{~cd}$ & $150.9 \mathrm{a}$ \\
\hline \multicolumn{2}{|c|}{ Fertilizers mean } & $137.2 \mathrm{~b}$ & $152.0 \mathrm{a}$ & $154.2 \mathrm{a}$ & \\
\hline \multicolumn{2}{|c|}{ Size } & & fertilizers & ean & Size mean \\
\hline & nall & $136.2 \mathrm{~b}$ & $152.6 \mathrm{a}$ & $154.1 \mathrm{a}$ & $147.679 \mathrm{a}$ \\
\hline & dium & $136.4 \mathrm{~b}$ & $151.7 \mathrm{a}$ & $154.3 \mathrm{a}$ & $147.532 \mathrm{a}$ \\
\hline & arge & $138.9 \mathrm{~b}$ & $151.7 \mathrm{a}$ & $154.3 \mathrm{a}$ & $148.351 \mathrm{a}$ \\
\hline & epth & Dep & $\mathrm{X}$ fertilize & nean & Depth mean \\
\hline & 5 & $123.5 \mathrm{e}$ & $163.7 \mathrm{~b}$ & $171.7 \mathrm{a}$ & $153.0 \mathrm{a}$ \\
\hline & 10 & $140.7 \mathrm{~d}$ & $141.1 \mathrm{~d}$ & $140.4 \mathrm{~d}$ & $140.7 \mathrm{c}$ \\
\hline & 15 & $147.4 \mathrm{c}$ & $151.2 \mathrm{c}$ & $150.6 \mathrm{c}$ & $149.7 \mathrm{~b}$ \\
\hline
\end{tabular}

Means followed by similar letters within factors or their interactions are not significantly different according to DMRT (1955), at 5\% probability. 
Table (9): Effect of seed size, sowing depth, phosphorus fertilization and their interaction on Harvest index (\%).

\begin{tabular}{|c|c|c|c|c|c|}
\hline \multirow{4}{*}{ Seed size } & \multicolumn{5}{|c|}{ Erbil location } \\
\hline & \multirow{3}{*}{$\begin{array}{c}\text { Sowing } \\
\text { depth }(\mathrm{cm})\end{array}$} & \multicolumn{3}{|c|}{ phosphorus fertilization } & \multirow{3}{*}{$\begin{array}{l}\text { Size X Depth } \\
\text { mean }\end{array}$} \\
\hline & & 0 & 75 & 150 & \\
\hline & & \multicolumn{3}{|c|}{ size, depth and fertilizers } & \\
\hline \multirow{3}{*}{ Small } & 5 & $28.9 \mathrm{~h}$ & $31.0 \mathrm{~h}$ & $28.4 \mathrm{~h}$ & $29.4 \mathrm{~b}$ \\
\hline & 10 & $36.9 \mathrm{~g}$ & $44.1 \mathrm{a}$ & $43.1 \mathrm{a}-\mathrm{d}$ & $41.3 \mathrm{a}$ \\
\hline & 15 & $40.6 \mathrm{c}-\mathrm{e}$ & $40.6 \mathrm{c}-\mathrm{e}$ & $40.3 \mathrm{c}-\mathrm{f}$ & $40.5 \mathrm{a}$ \\
\hline \multirow{3}{*}{ Medium } & 5 & $30.2 \mathrm{~h}$ & $30.4 \mathrm{~h}$ & $29.3 \mathrm{~h}$ & $30.0 \mathrm{~b}$ \\
\hline & 10 & $37.8 \mathrm{e}-\mathrm{g}$ & $43.2-d$ & $44.2 \mathrm{a}$ & $41.7 \mathrm{a}$ \\
\hline & 15 & $41.0 \mathrm{~b}-\mathrm{d}$ & $40.1 \mathrm{~d}-\mathrm{f}$ & $40.3 \mathrm{c}-\mathrm{f}$ & $40.5 \mathrm{a}$ \\
\hline \multirow{3}{*}{ Large } & 5 & $29.7 \mathrm{~h}$ & $30.5 \mathrm{~h}$ & $29.2 \mathrm{~h}$ & $29.8 \mathrm{~b}$ \\
\hline & 10 & $37.4 \mathrm{fg}$ & $43.6 \mathrm{ab}$ & $43.3 \mathrm{a}-\mathrm{c}$ & $41.4 \mathrm{a}$ \\
\hline & 15 & $40.4 \mathrm{c}-\mathrm{f}$ & $40.1 \mathrm{~d}-\mathrm{f}$ & $40.1 \mathrm{~d}-\mathrm{f}$ & $40.2 \mathrm{a}$ \\
\hline \multicolumn{2}{|c|}{ fertilizers mean } & $35.9 \mathrm{~b}$ & $38.2 \mathrm{a}$ & $37.6 \mathrm{a}$ & \\
\hline \multicolumn{2}{|c|}{ Size } & \multicolumn{3}{|c|}{ Size $X$ fertilizers mean } & Size mean \\
\hline \multicolumn{2}{|c|}{ Small } & $35.4 \mathrm{~d}$ & $38.6 \mathrm{a}$ & $37.3 \mathrm{a}-\mathrm{c}$ & $37.1 \mathrm{a}$ \\
\hline \multicolumn{2}{|c|}{ Medium } & $36.3 \mathrm{~b}-\mathrm{d}$ & $37.9 \mathrm{ab}$ & $37.9 \mathrm{ab}$ & $37.4 \mathrm{a}$ \\
\hline \multicolumn{2}{|c|}{ Large } & $35.8 \mathrm{~cd}$ & $38.1 \mathrm{a}$ & $37.5 \mathrm{ab}$ & $37.1 \mathrm{a}$ \\
\hline \multicolumn{2}{|c|}{ Depth } & \multicolumn{3}{|c|}{ Depth X fertilizers mean } & Depth mean \\
\hline \multicolumn{2}{|c|}{5} & $29.6 \mathrm{de}$ & $30.6 \mathrm{~d}$ & $28.9 \mathrm{e}$ & $29.7 \mathrm{c}$ \\
\hline \multicolumn{2}{|c|}{10} & $37.4 \mathrm{c}$ & $43.6 \mathrm{a}$ & $43.5 \mathrm{a}$ & $41.5 \mathrm{a}$ \\
\hline \multicolumn{2}{|c|}{15} & $40.6 \mathrm{~b}$ & $40.3 \mathrm{~b}$ & $40.2 \mathrm{~b}$ & $40.4 \mathrm{~b}$ \\
\hline \multicolumn{6}{|c|}{ Mosul location } \\
\hline \multirow{3}{*}{ Small } & 5 & $23.5 \mathrm{~d}-\mathrm{f}$ & $24.5 \mathrm{de}$ & $26.0 \mathrm{de}$ & $24.7 \mathrm{~d}$ \\
\hline & 10 & $36.5 \mathrm{bc}$ & $39.8 \mathrm{a}-\mathrm{c}$ & $35.4 \mathrm{c}$ & $37.2 \mathrm{c}$ \\
\hline & 15 & $42.3 \mathrm{a}$ & $40.3 \mathrm{a}-\mathrm{c}$ & $40.4 \mathrm{a}-\mathrm{c}$ & $41.0 \mathrm{a}$ \\
\hline \multirow{3}{*}{ Medium } & 5 & $19.2 \mathrm{f}$ & $24.9 \mathrm{de}$ & $27.0 \mathrm{~d}$ & $23.7 \mathrm{~d}$ \\
\hline & 10 & $38.1 \mathrm{a}-\mathrm{c}$ & $40.9 \mathrm{ab}$ & $35.3 \mathrm{c}$ & $38.1 \mathrm{bc}$ \\
\hline & 15 & $42.3 \mathrm{a}$ & $41.4 \mathrm{ab}$ & $40.8 \mathrm{ab}$ & $41.5 \mathrm{a}$ \\
\hline \multirow{3}{*}{ Large } & 5 & $21.5 \mathrm{ef}$ & $25.5 \mathrm{de}$ & $24.6 \mathrm{de}$ & $23.9 \mathrm{~d}$ \\
\hline & 10 & $38.3 \mathrm{a}-\mathrm{c}$ & $41.6 \mathrm{ab}$ & $37.5 \mathrm{a}-\mathrm{c}$ & $39.1 \mathrm{a}-\mathrm{c}$ \\
\hline & 15 & $40.2 \mathrm{a}-\mathrm{c}$ & $42.5 \mathrm{a}$ & $39.3 \mathrm{a}-\mathrm{c}$ & $40.7 \mathrm{ab}$ \\
\hline \multicolumn{2}{|c|}{ fertilizers mean } & $33.6 \mathrm{~b}$ & $35.7 \mathrm{a}$ & $34.0 \mathrm{~b}$ & \\
\hline \multicolumn{2}{|c|}{ Size } & Size & fertilizers & ean & Size mean \\
\hline & & $34.1 \mathrm{ab}$ & $34.9 \mathrm{ab}$ & $33.9 \mathrm{ab}$ & $34.5 \mathrm{a}$ \\
\hline & ium & $33.2 \mathrm{~b}$ & $35.7 \mathrm{ab}$ & $34.3 \mathrm{ab}$ & $34.4 \mathrm{a}$ \\
\hline & & $33.3 \mathrm{~b}$ & $36.5 \mathrm{a}$ & $33.8 \mathrm{ab}$ & $34.6 \mathrm{a}$ \\
\hline & & Dept & fertilizer & eean & Depth mean \\
\hline & & $21.4 \mathrm{e}$ & $25.0 \mathrm{~d}$ & $25.9 \mathrm{~d}$ & $24.1 \mathrm{c}$ \\
\hline & & $37.7 \mathrm{bc}$ & $40.8 \mathrm{a}$ & $36.1 \mathrm{c}$ & $38.2 \mathrm{~b}$ \\
\hline & & $41.6 \mathrm{a}$ & $41.4 \mathrm{a}$ & $40.2 \mathrm{ab}$ & $41.1 \mathrm{a}$ \\
\hline
\end{tabular}

Means followed by similar letters within factors or their interactions are not significantly different according to DMRT (1955), at 5\% probability. 


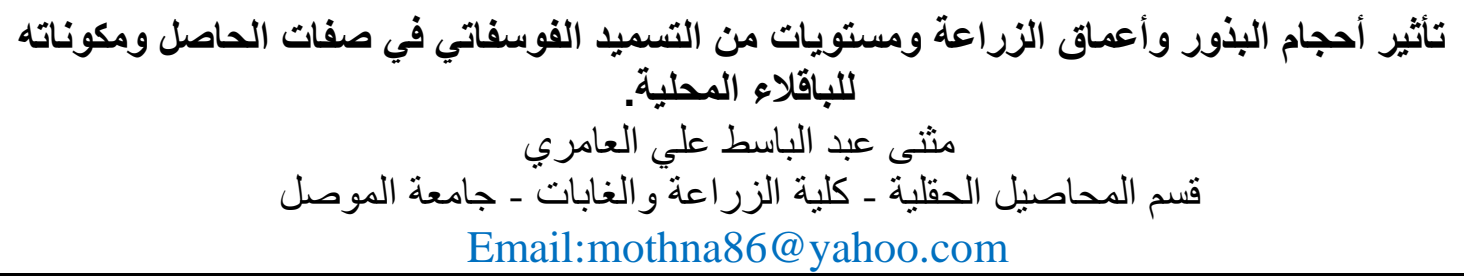

نفذت تجربة حقلية في موقعي (اربيل والموصل) للموسم الثتوي 2017-2018. لدراسة نأثير ثلاثة

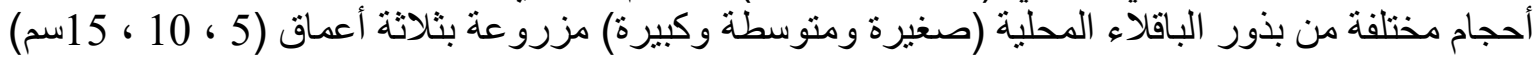
وباستخدام ثلاثة مستويات من التسميد الفوسفاتي (صفر و 75 و 150 كغم

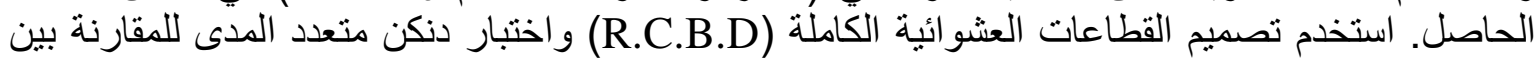

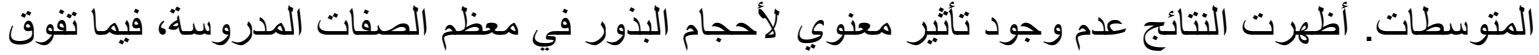

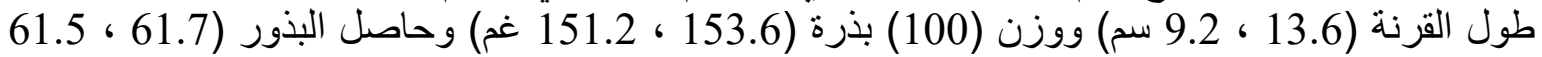

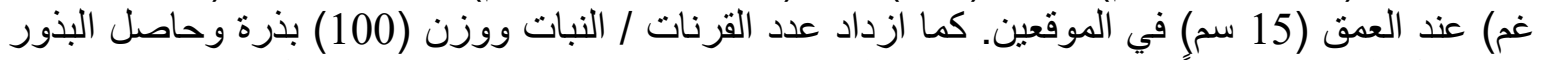

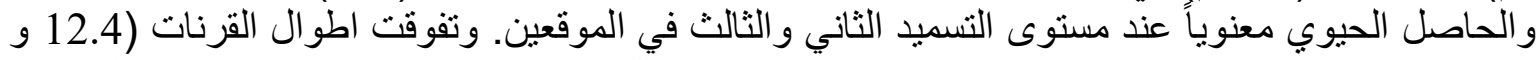

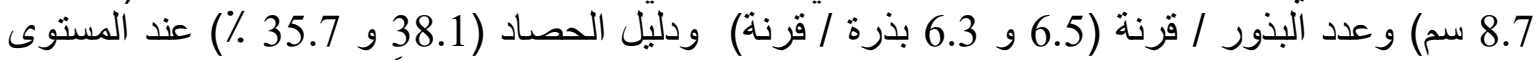

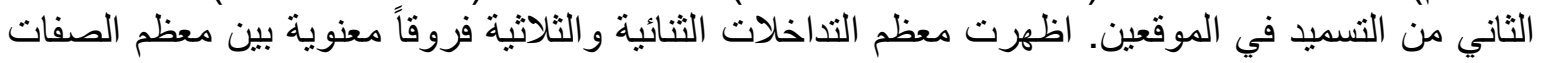

تاريخ استلام البحث: المفتاحية: الباقلاء، الحاصل، اعماق الزر اعة، التسمبد الفوسفاتي.

\section{REFREANCE}

AL- Rifaee, M. Munir A. Turki and Abdel R. M. Tawahai (2004). Effect of seed size and plant population density on yield and yield components of local Faba Bean (Vicia faba L. Major). International Journal Of Biology (2) :294-299.

Al-Anbari, M. A. Ibrahimi, Khalid A. H. Al-Tai and Saad F. H. (2010). Response of broad bean crop (Vicia faba L.) irrigation periods and sowing depths. Euphrates Journal Science of Agriculture . 2 (1): 6-15.

Arab Agricultural Development Organization, Khartoum, (2012). The Book of the Arab Agricultural Statistsics. Folder (32) p. 51.

Boras, Metwadi, Bassam Abu Trabi and Ibrahim Al-Basit (2006). Production of Vegetable Crops. Publications of Damascus University - Faculty of Agriculture.

Carmen, M. A.; Z. J. Carmen; S. Salvador; N. Diego; R. M. Maria Teresa, and T. Maria.(2005). Detection for agronomic traits in faba bean (Vicia faba L.). Agriculture Conspectus Science., 70(3) :17-20.

Central Bureau of Statistics and Information Technology, Agricultural Reports. (2010). Ministry of Planning and Development Cooperation - Iraq.

Hashemabadi, D. (2013). Phosphorus fertilizers effect on the yield and yield components of faba bean (Vicia faba L.). Annals of Biological Research, 4 (2) :181-184.

Hussain, Abed Sarab. Khalel Sh.Khalel and Haamead A.Habeeb. (2013). Effect of mulching by organic wastes. Depth of planting and seed size on seedling emergence and growth of broad bean in salinity soil. Diyala Agricultural Sciences Journal. 5(2): 173-184. 
Huthily, K. Hassan and Ali R. K. al-Hassani (2014). Effect of irrigation water salinity and phosphors fertilization on seeds and protein yield of Broad Bean (Vicia faba L.). AL-Muthanna Journal of Agricultural Sciences 2 (2): 65-72.

Idris, Abdel Latif Y. (2008). Effect of seed size and plant spacing on yield and yield components of Faba Bean (Vicia faba L.) Research Journal of Agriculture and Biological Sciences, 4(2): 146-148.

Issa. Saeed Salman (2009). Effect of phosphate fertilization on the growth and yield of the broad bean (Vicia faba L.) Euphrates Journal of Agriculture Science. 1(4): 47-51.

Kubure, T. E. Cherukuri. V. R. and Ibrahim. H. (2016). Production potential of Faba Bean (Vicia faba L.) genotypes in relation to plant densities and Phosphorus nutrition on vertisols of central highlands of west showa zone, Ethiopia, East Africa. Advance Crop Sciences Tech. 4(2) :2-9.

Mekkei, Mahmoud (2014). Effect of intra-row spacing and seed size on yield and seed quality of faba bean (Vicia faba L.). International Journal of Agriculture and Crop Sciences. 7 (10): 665-670.

Natalia, Gutierrez. C. M, Avila., M. T, Morenumber, and A. M, Torres .(2008). Development of SCAR markers linked to zt-2, one of the genes controlling absence of tannins in faba bean, Australia Journal of Agricultural Research., pp59

Sarkar, S. A. Sarkar and A. Zaman (2017). Effect of irrigation and phosphorus levels on broad bean (Vicia faba L.) for improving growth, yield and water extraction pattern. Legume Research, 40 (2): 257-263.

Sharma, R. C. and E. 1. Smith (1986) Selection for high and low harvest index in three winter wheat population. crop Sciences. 26. $\therefore(1117-1150)$.

Siddig, A.M. Ali and Abdellatif Y. Idris (2015). Effect of seed size and sowing depth on germination and some growth parameters of Faba Bean (Vicia faba L). Agricultural and Biological Sciences Journal. 1 (1) : 1-5.

Singh, A. K. R. C. Naresh. C. and Sushil. D. (2010). Effect of seed size and seeding depth on Fava Bean (Vicia faba L.) Productivity. Environment \& Ecology 28 (3A) : 1722-1727. 